2009

\title{
Health Insurance Exchanges: Legal Issues
}

Timothy S. Jost

Washington and Lee University School of Law, jostt@wlu.edu

This paper can be downloaded free of charge from:

http://scholarship.law.georgetown.edu/ois_papers/23 


\section{Legal Solutions in Health Reform}

\section{Health Insurance} Exchanges: Legal Issues

Timothy Stolzfus Jost, JD 


\section{O’Neill Institute}

for National and Global Health Law

\section{THE LINDA D. AND TIMOTHY J. O’NEILL INSTITUTE FOR NATIONAL AND GLOBAL HEALTH LAW}

AT

GEORGETOWN LAW

The O'Neill Institute for National and Global Health Law at Georgetown University is the premier center for health law, scholarship and policy. Housed at Georgetown University Law Center, in the heart of the nation's capital, the Institute has the mission to provide innovative solutions for the leading health problems in America and globally-from infectious and chronic diseases to health care financing and health systems. The Institute, a joint project of the Law Center and School of Nursing and Health Studies, also draws upon the University's considerable intellectual resources, including the School of Medicine, the Public Policy Institute, and the Kennedy Institute of Ethics.

The essential vision for the O'Neill Institute rests upon the proposition that the law has been, and will remain, a fundamental tool for solving critical health problems in our global, national, and local communities. By contributing to a more powerful and deeper understanding of the multiple ways in which law can be used to improve health, the O'Neill Institute hopes to advance scholarship, research, and teaching that will encourage key decisionmakers in the public, private, and civil society sectors to employ the law as a positive tool for enabling more people in the United States and throughout the world to lead healthier lives.

- Teaching. Georgetown is educating future generations of students who will become - upon their graduation - policymakers, health professionals, business leaders, scholars, attorneys, physicians, nurses, scientists, diplomats, judges, chief executive officers, and leaders in many other private, public, and nonprofit fields of endeavor. The O'Neill Institute helps to prepare graduates to engage in multidisciplinary conversations about national and global health care law and policy and to rigorously analyze the theoretical, philosophical, political, cultural, economic, scientific, and ethical bases for understanding and addressing health problems.

- Scholarship. O'Neill supports world-class research that is applied to urgent health problems, using a complex, comprehensive, interdisciplinary, and transnational approach to go beyond a narrow vision of health law that focuses solely on health care as an industry or as a scientific endeavor.

- Reflective Problem-Solving. For select high-priority issues, the O'Neill Institute organizes reflective problem-solving initiatives in which the Institute seeks to bridge the gap between key policymakers in the public, private, and civil society sectors and the intellectual talent and knowledge that resides in academia.

O’NEILL INSTITUTE FOR NATIONAL AND GLOBAL HEALTH LAW 


\section{OVERVIEW \\ LEGAL SOLUTIONS IN HEALTH REFORM}

The American public has increasingly identified health care as a key issue of concern. In order to address the multiple problems relating to the access and affordability of health care, President Obama and federal lawmakers across the political spectrum continue to call for major health reform. In any debate on health reform, a predictable set of complex policy, management, economic, and legal issues is likely to be raised. Due to the diverse interests involved, these issues could lead to a series of high-stakes policy debates. Therefore, it is critical that advocates of reform strategies anticipate such issues in order to decrease the likelihood that legally resolvable questions become barriers to substantive health reform. In an effort to frame and study legal challenges and solutions in advance of the heat of political debate, the O’Neill Institute for National and Global Health Law at Georgetown University and the Robert Wood Johnson Foundation have crafted the "Legal Solutions in Health Reform” project.

This project aims to identify practical, workable solutions to the kinds of legal issues that may arise in any upcoming federal health reform debate. While other academic and research organizations are exploring important policy, management, and economic questions relating to health reform, the O'Neill Institute has focused solely on the critical legal issues relating to federal health reform. The target audience includes elected officials and their staff, attorneys who work in key executive and legislative branch agencies, private industry lawyers, academic institutions, and other key players. This project attempts to pave the road towards improved health care for the nation by providing stakeholders a concise analysis of the complex legal issues relating to health reform, and a clear articulation of the range of solutions available.

\section{Legal Issues V. Policy Issues}

Among the major issues in federal health reform, there are recurring questions that are policybased and those that are legally-based. Many times questions of policy and of law overlap and cannot be considered in isolation. However, for the purpose of this project, we draw the distinction between law and policy based on the presence of clear legal permission or prohibition.

Under this distinction, policy issues include larger-scale questions such as what basic model of health reform to use, as well as more technical questions such as what threshold to use for poverty level subsidies and cost-sharing for preventive services. In contrast, legal issues are those involving constitutional, statutory, or regulatory questions such as whether the Constitution allows a certain congressional action or whether particular laws run parallel or conflict.

Based on this dividing line of clear permission or prohibition, policy questions can be framed as those beginning with, "Should we...?", and legal questions can be framed as those beginning with, "Can we...?" The focus of this paper will be the latter, broken into three particular categories: 1) "Under the Constitution, can we ever...?”; 2) "Under current statutes and regulations, can we now...?”; 3) “ Under the current regulatory scheme, how do we...?” This final set of questions tends to be mixed questions of policy, law, and good legislative drafting.

O’NEILl INSTITUTE FOR NATIONAL AND GLOBAL HEALTH LAW 


\section{Purpose and Layout of the Project}

This project is an effort to frame and study legal challenges and solutions in advance of the heat of political debate. This effort is undertaken with the optimistic view that all legal problems addressed are either soluble or avoidable. Rather than setting up roadblocks, this project is a constructive activity, attempting to pave the road towards improved health care for the nation. Consequently, it does not attempt to create consensus solutions for the identified problems nor is it an attempt to provide a unified field theory of how to provide health insurance in America. Furthermore, this project does not attempt to choose among the currently competing proposals or make recommendations among them. Instead, it is a comprehensive project written to provide policy makers, attorneys, and other key stakeholders with a concise analysis of the complex legal issues relating to health reform and a clear articulation of the range of solutions available for resolving those questions.

\section{LEGAL ISSUES}

Based on surveys of current health policy meetings and agendas, popular and professional press, and current health reform proposals, our team formulated a list of legal issues relating to federal health reform. After much research, discussion, and expert advice and review, our initial list of over 50 legal issues was narrowed to ten. An initial framing paper was drafted which identified these ten legal issues and briefly outlined the main components of each. In May of 2008, a bipartisan consultation session was convened to provide concrete feedback on the choice and framing of the legal issues. The attendees of the consultation session included congressional staff, executive branch officials, advocates, attorneys, employers, and representatives of a wide range of interests affected by health reform. Feedback and analysis from this session further narrowed the ten issues to eight key legal issues which warranted in depth analysis of the current law.

These eight pertinent issues are truly legal in nature and must be addressed in any significant reform proposal to avoid needless debate or pitfalls as policy decisions are made. There are multiple other legal issues that will arise as the discussion evolves and, if a federal policy is adopted, the system changes. In this project, however, we have targeted the issues essential for an immediate discussion of federal health reform.

O’NEILl INSTITUTE FOR NATIONAL AND GLOBAL HEALTH LAW 


\section{O’Neill Institute}

for National and Global Health Law

\section{LEgAL Solutions IN HEALTh REFoRM PROJECT}

JOHN T. MONAHAN, JD

Research Professor

Georgetown Health Policy Institute

Co-Director

Legal Solutions in Health Reform

JACQUELINE R. SCOTT, JD, ML

Adjunct Professor, Senior Fellow

Harrison Institute for Public Law

Georgetown Law

BENJAMIN E. BERKMAN, JD, MPH

Former Deputy Director \& Adjunct Professor

O’Neill Institute

Georgetown Law

\section{SHEILA P. BURKe, MPA, RN}

Research Professor

Georgetown Public Policy Institute

Distinguished Visitor, O’Neill Institute

Adjunct Lecturer and Senior Faculty Research

Fellow, Harvard University

John F. Kennedy School of Government

LisBeTH A. ZEgGANE

Former RWJF Project Assistant

O'Neill Institute
TIMOTHY M. WESTMORELAND, JD

Visiting Professor of Law

Georgetown Law

Co-Director

Legal Solutions in Health Reform

SARA P. HoverTer, JD, LLM

Staff Attorney, Adjunct Professor

Harrison Institute for Public Law

Georgetown Law

JACK EBELER, MPA

Distinguished Visitor, O’Neill Institute

Ebeler Consulting

SANDY H. HAN, JD, LLM

Teaching Fellow

Harrison Institute for Public Law

Georgetown Law

ELENORA E. CONNORS, JD, MPH

Fellow

O’Neill Institute

Georgetown Law

Mariesa M. Martin

RWJF Project Assistant

O'Neill Institute

Special thanks to the following individuals who contributed to the editing and production of the Legal Solutions in Health Reform Series, as well as the drafting of the Executive Summaries: Brian Bowen, Astrid Dorélien, Marissa Hornsby, Amy Killelea, Melanie MacLean, Anya Prince, and Luis Rodriguez. Also special thanks to John Kraemer for editing and production assistance. 


\section{LEGAL SOLUTIONS IN HEALTH REFORM \\ LEAD AUTHORS}

Executive Authority

Madhu Chugh, JD, MPP

Law Clerk

U.S. Court of Appeals for the D.C. Circuit

Washington, D.C.

Tax Credits for Health

Fred T. Goldberg, Jr., Esq.

Partner

Skadden, Arps, Slate, Meagher \& Flom, LLP

Washington, D.C.

\section{Insurance Exchanges}

Timothy S. Jost, JD

Robert L. Willet Family Professorship of Law

Washington \& Lee School of Law

Lexington, V.A.

Privacy and Security of Information

Deven McGraw, JD, LLM, MPH

Director, Health Privacy Project

Center for Democracy \& Technology

Washington, D.C.
Individual Mandates

Mark A. Hall, JD

Fred D. \& Elizabeth Turnpage

Professor of Law

Wake Forest University School of Law

Winston-Salem, N.C.

\section{ERISA}

Peter D. Jacobson, JD, MPH

Professor of Health Law \& Policy

Director, Center for Law, Ethics, and Health University of Michigan

School of Public Health

Ann Arbor, M.I.

Purchase of Insurance Across State Lines Stephanie Kanwit, JD

Special Counsel \& Healthcare Consultant America's Health Insurance Plans

Washington, D.C.

Insurance Discrimination Based on Health Status

Sara Rosenbaum, JD

Harold and Jane Hirsh Professor of Health

Law \& Policy

Chair, Department of Health Policy

The George Washington University School

of Public Health and Health Services

Washington, D.C. 


\section{ABOUt THE AUTHOR}

Timothy Stolzfus Jost, J.D., holds the Robert L. Willett Family Professorship of Law at the Washington and Lee University School of Law. He is coauthor of a casebook, Health Law, used widely throughout the United States in teaching health law and now in its sixth edition. He is also the author of Health Care at Risk, A Critique of the Consumer-Driven Movement, Health Care Coverage Determination: An International Comparative Study, Readings in Comparative Health Law and Bioethics, and numerous articles and book chapters on health care regulation and comparative health law and policy. He has written or is writing monographs on legal issues in health care reform for a number of other organizations including the National Academy of Public Administration, National Academy of Social Insurance, the Fresh Thinking Project, the Urban Institute and New America Foundation, and Academy Health.

The author wishes to thank the following individuals who provided valuable feedback in reviewing earlier drafts of this paper. Note, they are not responsible for its contents and they do not necessarily hold the views expressed here: Michael Curtis, Judge Donald L. Smith Professor in Constitutional and Public Law, Wake Forest University; Michael Gerhardt, Samuel Ashe Distinguished Professor of Constitutional Law, University of North Carolina; John McGinnis, Stanford Clinton, Sr. Professor of Law, Northwestern University; Wilson Parker, Professor of Law, Wake Forest University.

O’NeILl InSTITUTE FOR NATIONAL AND GLOBAL HEALTH LAW Georgetown LaW | 600 NEW Jersey AVENUE NW | WASHINGTON, DC 20001 www.oneillinstitute.org 


\section{EXECUTIVE SUMMARY \\ Prepared by the O'Neill Institute}

\section{INTRODUCTION:}

Health insurance exchanges (HIE) are entities that organize the market for health insurance by connecting small businesses and individuals into larger pools that spread the risk for insurance companies, while facilitating the availability, choice and purchase of private health insurance for the uninsured. While there are legal issues that warrant consideration under a federal, state, or private exchange framework, those issues are not insurmountable barriers to implementation.

The section below outlines the legal issues and solutions for a health insurance exchange if administered through the federal or state government or through a private entity.

FEDERAL EXCHANGES: Congress has the power to implement an HIE at the federal level, but must consider certain laws and regulations during both design and implementation as outlined below:

- Interstate Commerce: The federal government has the authority to regulate matters that substantially affect interstate commerce. While the power to regulate interstate commerce is not unbounded, the power certainly extends to insurance regulation.

- Tax and Spending: The federal government can tax and spend for the general welfare of citizens, thus Congress could use tax incentives and its spending power to incentivize participation in a federal exchange or to develop a "play or pay" framework with the states.

- McCarran Ferguson Act: Congress specifically delegated the regulation of insurance to the states. Therefore, Congress must clearly and explicitly communicate its intention to preempt state regulation of insurance in any insurance regulation it legislates.

- Anti-commandeering: The federal government is prohibited from appropriating state officials to implement federal laws. Therefore, a federal HIE must not require implementation by state employees.

- Due Process and Equal Protection: When selecting insurers for inclusion in the exchange, the federal government must act rationally when making legislative classifications and distinctions. This analysis will also apply to state exchanges.

- Takings Clause: Severe regulation of insurance has in a few instances been found by the courts to constitute a taking. This must be considered when determining the limitations that will be placed on insurance providers to encourage participation in the HIE. This analysis will also apply to state exchanges.

- Administrative Procedures Act: A federal HIE must comply with the standards and procedures relating to the freedom of information, records privacy, and adjudication applicable to all federal agencies.

- Other Considerations: A comprehensive review of the tax code, as well as employee benefit and public health laws should be conducted once the federal HIE has been designed.

O’NEILL INSTITUTE FOR NATIONAL AND GLOBAL HEALTH LAW 
STATE EXCHANGES: There are no insurmountable legal barriers to implementation of HIEs at the state level. Certain Constitutional issues that apply equally to state exchanges have been analyzed under the federal exchange framework and stated above.

- State Administrative Procedures Acts: Most, if not all, states have adopted legislation that outlines procedures for rulemaking, records privacy, adjudication, tort claims and government contracting. A state HIE must comply with existing state law, but these laws must be analyzed on a state by state basis.

- Employee Retirement Income Security Act (ERISA): Federal law preempts any state law that relates to an employee benefit health plan. A state HIE would only be preempted if participation by employers is mandatory or if the state requires action on the part of an employer.

- Health Insurance Portability and Accountability Act (HIPAA): Existing federal legislation contains non-discrimination, guaranteed access and pre-existing condition requirements that may need to be met by a state exchange if it offers insurance to employment-related groups.

PRIVATE EXCHANGES: Implementation of a private HIE is not prevented by existing state or federal law.

- Private Health Care Voluntary Purchasing Alliance Model Act: A number of states have adopted laws or regulations authorizing the creation of private exchanges. Review of existing laws would be required to ensure they adequately support a multi-insurer framework.

- Antitrust Laws: Current federal antitrust laws prohibit unreasonable restraints of trade. States, however, are exempt from antitrust law and could extend this exemption to private exchanges. Private exchanges can also be structured to avoid antitrust violations.

- Multiple Employer Welfare Arrangement Regulation (MEWAs): Membership and organizational rules will determine whether the state or federal government, or both, regulates private HIEs.

- HIPAA: The consumer safeguards provided by existing federal legislation likely would not apply to HIEs unless a contractual relationship was established that identified the exchange as a business associate of insurers. Under this agreement, HIEs would be limited in their ability to disclose personal health data to employers.

\section{CONCLUSION:}

Health insurance purchasing exchanges have been proposed as a possible means of making insurance more accessible, increasing competition among health plans, and promoting choice of insurer. President Obama's campaign proposal and various congressional leaders have proposed establishing insurance exchanges through federal legislation. Although exchanges implicate many design and policy issues regardless of whether they are implemented at a federal, state, or private entity level, there are no absolute legal bars to the establishment of health insurance exchanges.

O’NEILl INSTITUTE FOR NATIONAL AND GLOBAL HEALTH LAW 


\section{Legal Solutions in Health Reform: Health Insurance Exchanges: Legal Issues Timothy Stoltzfus Jost ${ }^{1}$}

\section{Introduction}

This Legal Solutions in Health Reform paper identifies and analyzes the legal issues raised by health insurance exchanges. Like all Legal Solutions papers, it does not purport to provide a concrete proposal as to how health insurance exchanges should be organized or even whether they should play a role in health care reform. Rather, it attempts simply to describe the legal issues that health insurance exchanges raise, and to propose alternative solutions to legal problems where useful. More specifically, it analyzes and offers alternative solutions to the legal problems raised by proposals to establish insurance exchanges by the federal government, by state governments, and by private entities or associations. Because the focus of this project and paper is on legal issues, discussion of policy and design issues is attenuated. Nevertheless, some attention to policy issues is unavoidable, because law is the realization of policy.

Health insurance exchanges are entities that organize the market for health insurance, much like stock exchanges do for securities or farmers' markets for produce. They are intended to facilitate the availability, choice, and purchase of private health insurance plans for individuals and the employees of small groups. They are usually government or non-profit institutions, but can be operated by the state or federal government or by private business associations or even by businesses. $^{2}$

Health insurance exchanges have been widely discussed as a solution to problems in the market for private health insurance. They figure prominently in the reform campaign plan proposed by President Obama, while a health insurance exchange, the "Connector," is at the heart of the much-discussed Massachusetts health reform program. ${ }^{3}$ The bipartisan Wyden-Bennett health insurance plan also relies on health insurance exchanges to organize the health insurance market. Another bipartisan bill, the Small Business Health Options Program Act of 2008 (S. 2795), has been introduced specifically to "establish a nationwide health insurance purchasing pool."4

At a minimum, exchanges centralize individual health plan enrollment and premium payments. They also provide information about insurance plans to those who purchase insurance through them, thus permitting individuals to compare the products of a number of insurers and to choose the best product for their needs. Exchanges can be used to facilitate employer payment for insurance premiums, including direct payments by individuals and payments collected by employers from employees through tax-advantaged Section 125 cafeteria arrangements or nontax-advantaged payroll deductions. ${ }^{5}$ They could also be used to facilitate the use of tax credits to purchase insurance. Some authors would limit exchanges to these functions, and indeed define exchanges in these terms. ${ }^{6}$

Other advocates would, however, give exchanges additional, more regulatory, responsibilities. Exchanges can, for example, define the benefits that participating plans must cover or specify the rating practices that they must follow with respect to exchange purchasers. The Obama campaign health plan would, for example, establish a national exchange to, "act as a watchdog group and help reform the private insurance market by creating rules and standards for participating insurance plans to ensure fairness and to make individual coverage more affordable

O’NEILl INSTitute FOR NATIONAL AND GLOBAL HEALTH LAW

GEORGETOWN LAW | 600 NEW JERSEY AVENUE NW | WASHINGTON, DC 20001 www.oneillinstitute.org 
and accessible." 7 The Obama exchange proposal would "require that all the plans offered are at least as generous as the new public plan and have the same standards for quality and efficiency." " It would also "evaluate plans and make the differences among the plans, including cost of services, transparent." " The State Health Help Agencies included in the proposed Wyden-Bennett Healthy Americans Act would be required to "develop standardized language for HAPI [Healthy American Private Insurance] plan terms and conditions and require participating health insurance issuers to use such language in plan information documents," as well as to ensure that plans follow the rating rules provided by the Act. ${ }^{10}$ The Massachusetts Connector, the most prominent currently existing example of an insurance exchange, also has extensive regulatory responsibilities, as described below. An exchange with regulatory responsibilities would look very much like the health alliances proposed by the Clinton Health Security Act or like various proposed purchasing cooperatives or like those created by the states during the 1990s.

In this paper, I will use the term "exchange" broadly to cover a range of entities, public and private, that 1) facilitate the purchase of private insurance plans by individuals and employees, and 2) make available to these individuals and employees a choice of a range of insurance plans. I include exchanges that perform additional regulatory functions. ${ }^{11}$

The best known contemporary model of a health insurance exchange is the Massachusetts Connector, a model that is being considered by a number of other states. ${ }^{12}$ The Massachusetts Connector is a quasi-public authority governed by a ten member board, with three members appointed by the governor, three members appointed by the attorney general, and four members who serve by virtue of their government positions. ${ }^{13}$ The Connector's responsibilities include: 1) facilitating the purchase of insurance by individuals and small groups (of 50 or fewer members) by providing a centralized exchange for the purchase of approved health insurance products and by collecting premium payments from individuals and employers and remitting these to insurers; 2) defining the criteria that insurance products must meet to offer minimum creditable coverage for purposes of the state's legal mandate that individuals purchase such coverage; 3) administering the new Commonwealth Care Health Insurance Program for lowerincome Massachusetts residents; 4) certifying if uninsured residents are unable to find insurance they can afford for purposes of being excused from the individual mandate; 5) establishing regulations for the $\S 125$ cafeteria arrangements that employers must establish under the Massachusetts reform; and 6) offering insurance at reduced rates for uninsured young adults between the ages of 18 and $26 .{ }^{14}$

Although some market advocates have hailed insurance exchanges (including the Connector) as a private market solution to the problems of health care cost, access, and quality, the Connector is in fact a quasi-government agency and many of its functions are regulatory. Moreover, the Connector has fewer regulatory responsibilities than might have been necessary to ensure a functioning insurance exchange in other states because the health insurance market in Massachusetts was already heavily regulated before the Connector was established. Even before the recent reforms, the insurance market in Massachusetts was subject to guaranteed issue requirements, modified community rating with no medical underwriting, a lengthy list of mandates, and a history of regulators refusing to approve high cost-sharing, low-benefit products (for which, in any event, there seemed to be little consumer demand). ${ }^{15}$

O’NEILL INSTITUTE FOR NATIONAL AND GLOBAL HEALTH LAW GEORGETOWN LAW | 600 NEW JERSEY AVENUE NW | WASHINGTON, DC 20001 www.oneillinstitute.org 
The Massachusetts Division of Insurance, rather than the Connector, continues to enforce these requirements. The Massachusetts reform also instituted an individual mandate, which plays a key role in controlling adverse selection against the Connector.

The extent to which exchanges act as regulators is only one of the ways in which exchanges can vary. Another very important variable is whether they are established at the federal, state, or local level. The Obama campaign proposal contemplates a national exchange as does the Small Business Health Options Program Act of 2008 (S. 2795), while the Wyden-Bennett proposal and state initiatives like the Massachusetts Connector locate exchanges at the state level. Additionally, private exchanges have been established by employers or by business coalitions. ${ }^{16}$ Although private exchanges lack regulatory authority, they have their own purported advantages - more flexibility in hiring and firing and the capacity to react more rapidly to changing conditions, for example.

With the election of President Obama, who campaigned on a platform of health reform, and strong Democratic majorities in both the House and Senate with leaders committed to health care financing reform - there is the real possibility of health reform legislation at the federal level. If we were assured that Congress would adopt legislation creating a national insurance exchange, this paper could be very short. The only legal limit on the ability of Congress to adopt legislation is the Constitution, and as will be discussed shortly, the Constitution imposes minimal constraints on the ability of Congress to act in this area. Congress would face serious policy and design problems in creating a national insurance exchange program, but those issues are not the focus of this paper.

It is important to remember, however, that we have been to the precipice of health insurance reform before, and Congress has not jumped. ${ }^{17}$ It is possible that the current economic crisis or other pressing policy priorities will delay or even derail health care financing reform. Were that to happen, the states would have to take the initiative, as some of them are doing now. Congress could remove some of the legal impediments that now limit state reforms. Steps it could take to facilitate the creation of insurance exchanges by the states are described below. But Congress might not even do that, leaving the states to navigate around existing law. The states, moreover, are facing their own fiscal crises, and many may take no action on their own if Congress fails to act. This could leave the private sector to take the initiative, and to find its way through the constraints of both federal and state law.

This paper will proceed to explore the legal issues presented by the range of possible futures of health care financing reform. It will first explore the limits that the law (primarily the Constitution) imposes on federal attempts to establish purchasing exchanges. Second, it will examine the constraints that federal law imposes on states that choose to establish insurance exchanges, considering both what Congress could do to remove these impediments and how the states can deal with them if Congress fails to act. Third, it discusses the legal constraints that the law imposes on private insurance exchanges. Although these constraints are imposed both by federal and state law, this paper will focus on the issues raised by federal law, noting that state law is varied and any concrete proposal for a private exchange would need to be analyzed in detail under the laws of the particular state in which it was to be operated. Finally, the paper will summarize the solutions it has suggested to the legal problems that it has identified.

O’NEILl INSTITUTE FOR NATIONAL AND GLOBAL HEALTH LAW GEORGETOWN LAW | 600 NEW JERSEY AVENUE NW | WASHINGTON, DC 20001 www.oneillinstitute.org 


\section{Federal Insurance Exchanges}

One possible approach, found in the Obama campaign plan, would be to establish a purchasing exchange at the federal level. Ensuring that health insurance is uniformly available across the country would be valuable in itself, and a national exchange could effectively address the problems of adverse and favorable selection issues that are the central conundrums of health insurance reform by creating massive risk pools. But a single national exchange could also pose serious administrative problems, particularly since there is little expertise in regulating insurance at the national level. It is quite possible, therefore, there would not be one central exchange under a national reform program, but rather exchanges established at the state or regional level. This is the solution that has been reached in regionalizing other federal programs. Examples of regional entities that have administered federal programs include Medicare contractors, Medicare Peer Review Organizations, and the Health Systems Agencies that were established under the National Health Resources and Development Act in the 1970s. Congress might even attempt to require the states themselves to establish purchasing exchanges. Of course, a single national exchange is not an impossibility. The Federal Employees Health Benefits program and the Medicare Advantage program are both administered at the national level.

Were a national plan to be established, it would face difficult design issues. Such issues would include: 1) determining the regions exchanges would cover, specifically whether they would be restricted by state lines or cover regions or multi-state metropolitan areas functioning like a single market; 2) the administrative relationship between exchanges and the central government, and whether the exchanges would be administered by private contractors (as in Medicare) or federal/state entities; and 3) the level of uniformity that would be required in the system, specifically whether premiums, coverage, and eligibility requirements would be the same across the country. ${ }^{18}$ I focus here, however, on legal rather than design problems.

\section{A. Federalism Issues}

First, implementation of a federal insurance exchange would require resolution of federalism issues. The first of these is the question of whether the federal government has the constitutional authority to regulate health insurance contracts, i.e. whether the sale of insurance contracts constitutes interstate commerce. The Supreme Court decided in 1944 that the federal government may constitutionally regulate insurance, ${ }^{19}$ and although there have been intervening decisions indicating that the federal government's interstate commerce authority is not unbounded, that power certainly extends to insurance regulation.

Congress would also need to consider the McCarran-Ferguson Act. In response to the Court's recognition in the 1940s that Congress had the power to regulate insurance contracts, Congress adopted a statute providing that "regulation and taxation by the several States of the business of insurance is in the public interest, and that silence on the part of the Congress shall not be construed to impose any barrier to the regulation or taxation of such business by the several States.” ${ }^{20}$ This means that Congress should not be considered to have preempted or superseded state law in the area of health insurance unless it does so expressly. This does not limit the power of Congress to create federal insurance exchanges; it merely means that Congress would have to do so explicitly.

O’NEILL INSTITUTE FOR NATIONAL AND GLOBAL HEALTH LAW GeORgETOWN LAW | 600 NEW JERSEY AVENUE NW | WASHINGTON, DC 20001 www.oneillinstitute.org 
Congress might attempt to implement a federal exchange program through the states, thus taking advantage of the insurance regulation institutions and experience of the states. In doing so, it would need to be mindful of the limitations the Constitution places on the power of the federal government to control the states. The Constitution has been interpreted to preclude Congress from passing laws that "commandeer" the authority of the states for federal regulatory purposes. $^{21}$ That is, Congress cannot require the states to participate in a federal insurance exchange program by simple fiat. This limitation, however, would not necessarily block Congress from establishing insurance exchanges. Congress could invite state participation in a federal program, and provide a federal fallback program to administer exchanges in states that refused to establish complying exchanges. ${ }^{22}$ Alternatively it could exercise its Constitutional authority to spend money for the public welfare (the "spending power"), either by offering tax subsidies for insurance only in states that complied with federal requirements (as it has done with respect to tax subsidies for health savings accounts) or by offering explicit payments to states that establish exchanges conforming to federal requirements. ${ }^{23}$

\section{B. General Constitutional Constraints (Which Apply Also to State Insurance Exchanges)}

In addition to federalism issues, there are a variety of general constitutional issues that would affect government exchanges. These issues would also apply to state and federally-established exchanges, but are discussed only in this section to avoid duplication. One of the functions that an insurance exchange must fulfill is deciding which insurers can sell their products through the exchange. Five possibilities here are readily apparent. First, an exchange could allow any insurer to sell its products through the exchange that wanted to do so. Second, the exchange could permit all insurers to participate that agreed to comply with certain standards to sell their products, effectively an "any willing provider" approach. Third, the exchange could negotiate with insurers and only allow those to participate that concluded satisfactory negotiations to offer their products through the exchange. Fourth, the exchange could decide to limit the number of insurers allowed to offer their products through the exchange, and then devise a process for deciding which insurers would make the cut-off, and which would not. Finally, the state could not only bar some insurers from the exchange, but limit all insurance purchases (perhaps in the individual and small group market) to insurers participating in the exchange, effectively prohibiting any residents of the state from purchasing insurance from non-participating insurers.

One of the primary advantages of an exchange is that it permits choice of insurers, particularly for employees of small businesses. Allowing broad participation of insurers, therefore, would seem desirable. On the other hand, another ideal that grounds health insurance exchanges is that of organizing or structuring competition among insurers. Indeed, there is some evidence that too many choices can be confusing to consumers. ${ }^{24}$ Thus it might make sense for exchanges to limit the number of insurers and participating plans and to structure competition among those insurers. Indeed, insurers might be prohibited from selling policies to individuals or small groups except through the exchange. Insurance exchanges might also be required to regulate the rating practices or benefit packages of insurers who sell policies through them, thus limiting participating insurers to those that accept limitations on these practices.

If insurance exchanges are government-run or sponsored, their exclusionary or regulatory interventions may raise constitutional issues. ${ }^{25}$ The Due Process Clause of the Constitution requires the government to act rationally when it engages in social and economic regulation, while the Equal Protection Clause requires the government to make rational legislative

O’NEILL INSTITUTE FOR NATIONAL AND GLOBAL HEALTH LAW

GEORGETOWN LAW | 600 NEW JERSEY AVENUE NW | WASHINGTON, DC 20001 $\frac{\text { www.oneillinstitute.org }}{7}$ 
classifications and distinctions. The U.S. Constitution and most states' constitutions prohibit the taking of private property for public use without just compensation. Finally, state governments are under an additional constraint of the Contracts Clause of the U.S. Constitution prohibiting states from adopting laws that impair "the obligation of contracts." 26

Government regulation of economic conduct is acceptable under the Due Process and Equal Protection clauses as long as it bears a rational relationship to a legitimate government interest. ${ }^{27}$ Similarly, Contracts Clause challenges will not succeed unless a challenged regulation "substantially impairs a contractual relationship," does not promote a significant and legitimate public interest, and is based on unreasonable conditions unrelated to the public purpose. ${ }^{28}$ Finally, a regulatory law can be challenged under the takings clause, which bars the government from taking private property for public use without just compensation, if the law goes "too far" in the severity of its impact and in frustrating distinct "investment-backed expectations." 29

Insurance has long been a heavily regulated industry, and constitutional challenges to requirements imposed by an exchange through regulation or negotiation are unlikely to succeed unless the requirements are wholly irrational. ${ }^{30}$ Courts have repeatedly rejected constitutional challenges to state insurance mandates, including statutes requiring insurers to provide maternity coverage $^{31}$ and coverage for mental disorders. ${ }^{32}$ In the one reported constitutional case actually involving an insurance purchasing exchange, a federal court in Kentucky rejected Due Process and Commerce Clause challenges brought by an insurer against a statutory requirement that insurers offer only standard plans approved by a health policy board. ${ }^{33}$ State statutes that specifically restrict participation in markets by insurers have also been upheld. ${ }^{34}$ In analogous areas, courts have upheld the constitutionality of certificate of need programs, which prohibit private health care providers from entering markets or expanding their market participation without permission from the state, ${ }^{35}$ as well as federal Medicare amendments that prohibit physicians from selling their services to Medicare beneficiaries outside of the Medicare program unless the physician left the Medicare program for two years. ${ }^{36}$

Probably the category of constitutional challenges most likely to succeed against reform laws establishing exchanges are those brought under the Takings Clause. To this point, all such challenges have been brought against state rather than federal insurance regulation, although the Takings Clause applies equally to both federal and state governments. In a number of cases in recent years particularly severe state laws regulating insurance have been successfully challenged under the Takings Clauses of the U.S. or of state constitutions, prominently among them laws rolling back or freezing rates, requiring insurers to fund residual markets using profits from other states or lines of business, or restricting insurers from exiting markets. ${ }^{37}$

The success of these challenges, however, seems to be specific to particular jurisdictions. For each instance in which a challenge has succeeded against a particular kind of law, similar laws in other jurisdictions have survived similar constitutional challenges. For example, in a case involving New York's attempt to create a risk pooling mechanism, a court observed that an insurer has no "constitutionally protected interest in maintaining a healthier than average risk pool." 38 As insurers face increasingly comprehensive regulation analogous to that traditionally faced by public utilities, a body of federal or state constitutional law may evolve providing insurers the right to make a just and reasonable return on their investment like that currently claimed by public utilities. ${ }^{39}$ It remains true; however, that government retains considerable discretion in regulating a wide range of insurer behavior.

O’NEILl INSTITUTE FOR NATIONAL AND GLOBAL HEALTH LAW

GEORGETOWN LAW | 600 NEW JERSEY AVENUE NW | WASHINGTON, DC 20001 www.oneillinstitute.org 
Congress must take care that any insurance exchange program it initiates and operates is nondiscriminatory and does not engage in confiscatory regulation. It is unlikely that the Constitution will, however, prove a significant barrier to the development of reasonable insurance exchanges.

\section{Other Legal Issues Raised by Federal Insurance Exchanges}

An insurance exchange established by federal law will presumably be an agency subject to the Administrative Procedures Act, including provisions relating to the freedom of information, records privacy, open meetings, rulemaking, adjudication, and judicial review. ${ }^{40}$ Certain aspects of the program might also be subject to the Federal Acquisitions Regulations promulgated pursuant to 41 U.S.C. $\S 405$, which govern federal purchases of products and services. These provisions would need to be considered in designing the exchange.

If Congress were to create federal purchasing exchanges it would also need to amend a number of federal laws to clarify the relationship between federal and state regulatory power. The most obvious of these would be the Employee Income Retirement Security Act of 1974, which is discussed below. Once the design of a federal insurance exchange became clear, a comprehensive review of the federal tax, employee benefit, and public health laws would be necessary to make sure that they properly reflected the balance of federal and state regulatory power contemplated by the purchasing exchange program.

\section{State Insurance Exchanges}

\section{A. Constitutional Law}

The constitutional law issues that affect state insurance exchanges were discussed in the previous section and will not be repeated here.

\section{B. Governance Issues}

If an exchange is established as a state agency, it will be subject to state administrative law. About two thirds of the states have adopted some version of the Model State Administrative Procedures Act (APA). The Model State APA prescribes procedures for rule making, adjudication, and judicial review. Each state also has an open meetings and freedom of information statute. ${ }^{41}$ State-run insurance exchanges will presumably be subject to these laws unless they are specifically exempted by statute. ${ }^{42}$ They will also presumably be subject, like other state agencies, to state laws addressing civil service, government contracting, and government tort claims. These laws vary from state to state, and cannot be discussed in detail here.

Another issue that will have to be addressed is how a state insurance exchange interfaces with other state agencies. This is primarily a design issue, but will require the drafting of new laws or the amendment of existing laws for implementation. The Massachusetts Connector was established as an independent authority, but the Massachusetts Division of Insurance continues to regulate health insurance plans generally, while the Department of Finance is responsible for enforcement of the individual mandate. The National Association of Insurance Commissioners (NAIC) has adopted both a "Single Health Care Voluntary Purchasing Alliance Model Act" (78-

O’NEILl INSTITUTE FOR NATIONAL AND GLOBAL HEALTH LAW

GEORGETOWN LAW | 600 NEW JERSEY AVENUE NW | WASHINGTON, DC 20001 www.oneillinstitute.org 
1) and a "Regional Health Care Voluntary Purchasing Alliance Model Act" (80-1) which presents the states with different options for creating exchanges at the state or regional level. These statutes would place regional alliances under the state commissioner of insurance, but establish a separate state agency for the single state exchange authority. The Single State Exchange Model Act states in a drafting note,

This Act establishes the purchasing alliance as a state agency. However, states may wish to establish the purchasing alliance as a state-chartered nonprofit organization. States may also consider establishment under an existing state agency such as the office of commissioner." 43

States will also have to coordinate between the purchasing alliance and other state agencies, including: 1) the agency responsible for the Medicaid and State Children's Health Insurance Program, if Medicaid or SCHIP recipients are covered through the purchasing pool; 2) the entity that purchases care for state employees or retirees, if state employees or retirees are covered through the purchasing pool; 3) the state health insurance assistance program; and 4) any separate agency that regulates managed care, if applicable.

\section{Issues Raised by Federal Law}

If health insurance reform proceeds primarily at the state rather than the federal level, the states will need to come to terms with federal laws that limit their options. To date, as noted above, insurance regulation has primarily been the responsibility of the states. Congress has, however, adopted a number of laws partially preempting state authority over health insurance, particularly in the area of employee benefits. If the federal government assumes responsibility for health care financing or its regulation, these laws will presumably be repealed or comprehensively amended to transfer the responsibility of insurance regulation from the states to the federal government. If Congress decides rather to leave health reform to the states, Congress could repeal or amend these laws to afford the states the freedom to enact their own reform programs. If Congress does nothing, the states will have to adapt to these laws as they exist. This section explores the latter two possibilities.

\section{Employee Retirement Income Security Act of 1974 Preemption}

In general, preemption is a legal principle that bars state regulation of a subject if federal law expressly precludes state regulation, if the state regulation would conflict with federal law, or if the federal government comprehensively regulates an area of activity, thus excluding state regulation. For example, the Employee Retirement Income Security Act (ERISA) regulates the administration of employer sponsored benefit plans including health benefits. One of the issues that state established exchanges face is the possibility of ERISA preemption - that is that the federal ERISA statute will bar states from establishing and operating insurance exchanges in the manner they would prefer. The general law of ERISA preemption is fully addressed in another Legal Solutions in Health Reform authored by Peter Jacobson. The importance of ERISA, however, justifies some consideration here. ERISA is also discussed further in the next section with respect to the question of whether its multiple employer welfare arrangements (MEWA) provisions affect private plans.

O’NEILl INSTITUTE FOR NATIONAL AND GLOBAL HEALTH LAW

GeORgETOWN LAW | 600 NEW JERSEY AVENUE NW | WASHINGTON, DC 20001 www.oneillinstitute.org 
Section 514 of ERISA explicitly preempts any state law that "relates to" an employee benefits plan. $^{44}$ The Supreme Court has interpreted this provision to mean that any state law is preempted that has "a connection with or reference to" a benefits plan. ${ }^{45}$ Although ERISA also provides that state laws that regulate insurance are saved from preemption, it further stipulates that states may not regulate self-insured insurance plans. Finally, section 502 of ERISA has been construed by the Supreme Court to preclude any state judicial remedies against ERISA plans. ${ }^{46}$

In the insurance exchange context, ERISA preemption is likely to be an issue only with respect to state laws that seek some way to compel an employer to establish an employee benefit plan or to compel an employee benefit plan to participate in an exchange. It should not affect state insurance exchanges in which participation is strictly voluntary and which do not require action to be taken by either an employer or an employee benefits plan. ERISA would also not affect private exchanges that do not have legal authority to require employers or benefit plans to participate. $^{47}$ ERISA explicitly saves from preemption state laws regulating insurance, ${ }^{48}$ and thus ERISA would not limit a state's ability to require insurers to sell their products through an insurance exchange or to regulate the products insurers sell through exchanges. This is consistent with the long-standing policy of Congress, articulated in the McCarran-Ferguson Act, to leave the regulation of insurance to the states. ERISA should also not preclude a state from requiring individuals to purchase insurance through an insurance exchange. ${ }^{49}$

ERISA, however, does impose significant limitations on the states. ERISA almost certainly prohibits states from requiring any employer offering health benefits to provide those benefits through an exchange. Such a law would be seen as a law "relating to" an ERISA benefits plan, preempted by federal law. ${ }^{50}$ ERISA might also preclude states from imposing a requirement directly on employers who do not currently provide health insurance benefits to begin providing health insurance through an exchange or to pay an assessment to the state. Federal courts are now split on the question of preemption of state "pay or play" laws and the enforceability of such laws may turn on their precise provisions. ${ }^{51}$ Finally, it would be unwise for a state insurance exchange statute to explicitly mention ERISA plans lest it fall afoul of the "reference to" prohibition. In one case, for example, the Supreme Court held that a state law prohibiting garnishment of ERISA benefits to be preempted because of the explicit reference to ERISA plans in the law. ${ }^{52}$

One unsettled issue is whether ERISA would prohibit states that establish insurance exchanges from requiring employers who do not otherwise offer health insurance to forward payments, taken out of their employees' wages on a payroll deduction basis, to the exchanges, through a section 125 Cafeteria arrangement. ${ }^{53}$ A section 125 Cafeteria arrangement allows an employer to withhold a sum of money specified by the employee on a pre-tax basis from an employee's wages, and allows the employee to use that money to purchase certain specific benefits. ${ }^{54}$ States considering health insurance reform in general and health insurance exchanges in particular have found the section 125 option of particular interest. Specifically, the section 125 option allows employees to obtain federal tax subsidies for their own expenditures so that they can purchase insurance through an exchange, assuming that ERISA does not allow the states to require employers to offer their employees health insurance purchased through an exchange. The Massachusetts law, as noted above, requires employers with more than 11 workers (under the threat of a penalty if other conditions are met) to establish section 125 arrangements for their employees, through which funds may be channeled to the Connector to purchase health insurance.

O’NEILl INSTITUTE FOR NATIONAL AND GLOBAL HEALTH LAW GEORGETOWN LAW | 600 NEW JERSEY AVENUE NW | WASHINGTON, DC 20001 www.oneillinstitute.org 
As discussed below, it is arguable that a section 125 arrangement is a "group health plan" under the Internal Revenue Code. It could be argued by extension that it is also an ERISA plan, and thus that ERISA prohibits states from requiring employers to establish section 125 Cafeteria arrangements through which employee contributions can be channeled to insurance exchanges. There are, however, convincing arguments that section 125 arrangements are not ERISA plans. First, ERISA defines an employee benefits plan as a plan "established or maintained" by an employer. $^{55}$ In several instances, courts have found that an ERISA plan did not exist when employers simply assisted employees in paying individual health or disability insurance premiums from the employee's own funds without further involvement in the insurance relationship. $^{56}$

Second, the Labor Department regulations establish a safe harbor that excludes from the ERISA plan definition "group or group-type" insurance arrangements if five conditions are met: 1) the employer does not contribute its own funds; 2) employee participation is voluntary; 3) the employer does not "endorse" the arrangement; 4) the employer does nothing more than to allow an insurer to publicize the arrangement to employees and to collect premiums through payroll deductions; and 5) the employer receives no consideration beyond reasonable compensation for administrative services. ${ }^{57}$

There are dozens of cases litigating the application of this safe harbor to particular arrangements, usually in the context of an insurer seeking the protection of ERISA preemption against a state law claim brought by an aggrieved member. This litigation generally focuses on the third safe harbor criterion-the prohibition against endorsement by an employer. The cases tend to hold that if an objectively reasonable employee would conclude that an employer has not simply made a plan available, but has also exercised control over the plan or made it appear to be part of the employer's own benefit package, the arrangement will be considered an ERISA plan. If an employer becomes actively involved in the promotion or administration of a plan funded through a section 125 arrangement, courts are likely to find the plan to be an ERISA plan on employer endorsement grounds. ${ }^{58}$

If, on the other hand, an employer simply collects premiums from employees on a payroll deduction basis and forwards them to insurers, courts should find that no ERISA plan exists. ${ }^{59}$ If a section 125 Cafeteria arrangement exists solely by operation of a state law requirement, and the employer has taken no action to endorse the purchase of insurance through the arrangement other than to comply with state law, it is difficult to see why the arrangement would not fit within the ERISA safe harbor. ${ }^{60}$ The argument that an employer has not endorsed a plan would be particularly strong if a state directed employee funds collected under a section 125 arrangement to a purchasing exchange rather than to a particular insurance plan, as the employee and not the employer would be choosing the employee's insurance plan through the exchange. ${ }^{61}$

Third and finally, the only Department of Labor advisory opinion examining the question of ERISA and section 125 arrangements concluded that a section 125 arrangement was not "the equivalent of the provision of a benefit enumerated under" the ERISA definition of an ERISA plan. $^{62}$ Thus a state requirement that employers allow their employees to pay for health benefits through a state insurance purchasing exchange by way of a section 125 arrangement would not seem to be preempted by ERISA.

O’NEILl INSTITUTE FOR NATIONAL AND GLOBAL HEALTH LAW GEORGETOWN LAW | 600 NEW JERSEY AVENUE NW | WASHINGTON, DC 20001 www.oneillinstitute.org 
Congress could, of course, amend section 125 of the Tax Code and ERISA to clarify that the states can require employers to establish section 125 arrangements to allow employees to purchase individual health insurance policies, including policies purchased through a statesponsored health insurance exchange. The Department of Labor could probably accomplish the same end through an administrative regulation or ruling, given the uncertainty in this area. Alternatively, Congress could simply extend the tax subsidies currently offered in employmentrelated health insurance to individual insurance, which would obviate the need for section 125 arrangements. In the absence of any amendments in the federal law, however, it appears that the states are permitted to require employers to establish section 125 plans for the purchase of insurance through health insurance exchanges, as Massachusetts has done.

\section{The Health Insurance Portability and Accountability Act}

The application of another federal law, the insurance portability provisions of the Health Insurance Portability and Accountability Act (HIPAA), raises other legal issues that would affect the implementation of an insurance exchange at the state level. The specific issue is whether an arrangement where an employer pays insurance premiums for its employees through an insurance exchange creates a group health plan under HIPAA.

HIPAA prohibits group health plans and health insurance issuers from discriminating on the basis of health status in determining eligibility or premiums for members of group health plans. HIPAA imposed these requirements through amendments to ERISA, the Public Health Service Act, and the Internal Revenue Code (the "Tax Code"), all of which are quite similar. ${ }^{63}$ These provisions effectively require guaranteed issue and community rating to individuals within group health plans without regard to health status. If HIPAA applies to purchases of insurance for employees through an insurance exchange, insurers would not be able to underwrite individual employees who purchase insurance through the exchange separately, but would need to offer insurance to all otherwise eligible employees of any single employer and offer them the same rate. Other provisions of HIPAA require guaranteed issue and renewal for group plans and limit the use of preexisting conditions clauses within group plans. ${ }^{64}$ These provisions would also apply if employees of a single employer who purchase insurance through an exchange were treated as a single group. The application of HIPAA to state health insurance exchanges would not preclude the creation of exchanges, but it would have clear implications for their design. Instead of simply facilitating the purchase of individual insurance policies through a coordinated market, exchanges would rather be coordinating the sale of policies to employment-related groups (in addition to individuals who were not employed).

The ERISA provision of HIPAA, 29 USC $\S 1182$, adopts the ERISA definition of "group health plan" discussed above, under which the key question is whether the plan is "established or maintained" by the employer. ${ }^{65}$ If an employer pays part of the cost of the premium or in some other way endorses a plan purchased through an exchange, HIPAA would apply and the above requirements would apply to the plan purchased through the exchange. This is true even though the employer pays for separate individual policies for each employee, a so called "list billing" arrangement. $^{66}$ If an employer, however, neither contributes to the cost of insurance for employees nor "endorses" a plan, it would seem that policies purchased on a payroll deduction basis (for example, through a section 125 arrangement) would not be subject to the HIPAA nondiscrimination, small group coverage, or pre-existing conditions rules under the ERISA statute, but would simply be individual insurance policies. ${ }^{67}$

O’NEILL INSTITUTE FOR NATIONAL AND GLOBAL HEALTH LAW

GEORGETOWN LAW | 600 NEW JERSEY AVENUE NW | WASHINGTON, DC 20001 www.oneillinstitute.org 
The HIPAA requirements, however, are also found in the Tax Code, which incorporates the Tax Code definition of "group health plan." The Tax Code defines the term "group health plan" somewhat differently than does ERISA. It defines a group health plan as a "plan (including a self-insured plan) of, or contributed to by, an employer (including a self-employed person) or employee organization to provide health care (directly or otherwise) to the employees" (emphasis added). ${ }^{68}$ This definition raises issues if a state attempts to require employers to fund health insurance purchases by requiring employers to establish section 125 arrangements.

Section 125 regulations recently proposed by the Department of the Treasury explicitly permit payment of individual health insurance premiums from a section 125 arrangement, either directly to the insurer or on an indemnity basis to the employee, suggesting that the individual policies do not become group policies simply because the employer collects and remits premium payments. $^{69}$ Section 125, however, only exempts from taxation expenditures for "qualified benefits," i.e. benefits otherwise exempt from taxation under other sections of the Tax Code. ${ }^{70}$ The relevant provision of the Tax Code exempting health benefits is section 106, which excludes "employer-provided coverage."

Arguably, therefore, insurance provided through a section 125 arrangement is a group health plan under HIPAA because it is "employer-provided." It can also be argued that a section 125 arrangement is a group health plan because it is funded by an employer contribution, because the statute provides that funds in a section 125 arrangement are not part of an employee's gross income, and thus might be considered funds contributed by an employer. The IRS has informally taken the position that the use of section 125 arrangements to purchase individual policies makes them group policies for purposes of the Tax Code, and thus for the HIPAA provisions of the Tax Code. ${ }^{71}$ In this view, insurance policies purchased by employees of a single employer through an insurance exchange with the funds provided under a section 125 arrangement would have to comply with the HIPAA non-discrimination, guaranteed access and renewability, and pre-existing conditions requirements of HIPAA.

The entire issue of the application of HIPAA is avoided, of course, if a state itself requires community rating, guaranteed issue and renewal, and limits pre-existing conditions clauses from insurers offering insurance through an insurance exchange. Federal requirements under HIPAA would, in that case, be superfluous. Congress could also amend HIPAA to clarify either that HIPAA does or does not apply to insurance policies purchased through exchanges with section 125 funds. The Internal Revenue Service could also possibly clarify this issue through a regulation or some other form of guidance. Alternatively, Congress could simply extend the requirements of HIPAA to all health insurance policies. If Congress does not change the law, however, and a state allows insurers to underwrite and rate individuals covered through the exchange individually, it would seem that the insurers would not be able to do so within ERISA group health plans and within groups of individuals whose premiums are paid by a single employer through a section 125 arrangement.

\section{State Regulation of Underwriting, Premiums, and Benefits}

States that regulate non-group insurance or insured ERISA plans are permitted to regulate insurance underwriting, premium rates, and benefits. Most states do so to a greater or lesser extent. $^{72}$ States, for example, require insurers to guarantee coverage and renewal to small groups

O’NEILl INSTITUTE FOR NATIONAL AND GLOBAL HEALTH LAW

GEORGETOWN LAW | 600 NEW JERSEY AVENUE NW | WASHINGTON, DC 20001 www.oneillinstitute.org 
(implementing HIPAA), while some states go further, requiring insurers to offer community rates to small groups or individuals or limit the dispersion of rates through rating bands. States also require insurance plans to cover specific benefits, providers, and eligible individuals. The extent to which states regulate underwriting, premium rates, and benefit coverage is a matter of public policy rather than law. The policy arguments for and against underwriting, rating, and benefit coverage mandates are well known (and passionately asserted), and will not be repeated here. $^{73}$ Since these forms of regulation must be implemented by state law, however, they will be addressed briefly here.

States that create public or authorize quasi-public purchasing exchanges can apply underwriting, rating regulation, and coverage mandates either generally to the entire insurance market or only within the purchasing exchange. A state is free to make its own policy choices in determining which approach to take, as long as it does not attempt to apply such laws to self-insured ERISA plans or permit the violation of HIPAA requirements with respect to group plans.

If a state attempts to apply underwriting and rating requirements within an insurance exchange that are not applied generally in the relevant market, or attempts to impose benefit mandates within an exchange that are not imposed generally, it exposes the exchange to adverse selection, which might make the arrangement untenable. ${ }^{74}$ If insurers are allowed to underwrite in the market generally, but not within the insurance exchange, the exchange may in effect become a high-risk pool. If insurers are required to community rate within the insurance exchange but not otherwise, they may not participate in the exchange. If states require insurers to offer more generous benefits within the exchange than they can outside of it, the rates for exchange products may become comparatively unattractive.

Community rating is not the only available strategy to make insurance purchased through an insurance exchange affordable to persons with poor risk profiles. An insurance exchange could also, for example, collect premiums (and tax credits or other forms of public insurance vouchers) and then pay out premiums on a risk-adjusted basis, as Medicare does with Medicare Advantage and the Part D drug benefit plan premiums. Alternatively, insurers selling their products through the risk pool could be required to participate in a risk reinsurance pool, so that plans would not be disadvantaged by taking higher risk insureds. Third, a public reinsurance program could be provided to backstop insurers who cover the highest risks. ${ }^{75}$ Fourth, the simple imposition of an individual mandate could create a large enough risk pool that insurers would be comfortable taking on greater risk exposure. Finally, simply providing substantial state subsidies for individuals who purchase insurance through an exchange (but not otherwise) would go far toward reducing adverse selection against exchange insurers. Each of these solutions, however, may create additional responsibilities for exchanges.

\section{Private Exchanges}

If exchanges are created neither by the federal nor state government, but rather privately by business coalitions or groups of employers, they face a different set of legal issues. ${ }^{76}$ These entities must comply with state laws regulating insurance. The NAIC has a "Private Health Care Voluntary Purchasing Alliance Model Act,"77 and a number of states have adopted laws or regulations authorizing the creation of insurance exchanges. ${ }^{78}$ State insurance laws regulating association health plans should also be reviewed to determine if they affect particular

O’NEILl INSTITUTE FOR NATIONAL AND GLOBAL HEALTH LAW

GEORGETOWN LAW | 600 NEW JERSEY AVENUE NW | WASHINGTON, DC 20001 www.oneillinstitute.org 
arrangements, although exchanges should be distinguishable from Association Health Plans (AHPs) because exchanges offer a choice of a number of insurers while AHPs usually provide insurance themselves either through self-insurance or by contract. ${ }^{79}$ Some states prohibit list billing, which could close off one approach to funding employee health care through purchasing exchanges. ${ }^{80}$

Exchanges would, moreover, have to comply with their contractual obligations and could face claims under business torts. Both regulatory and common law vary from state to state, and a fifty state survey of all state insurance regulations that might affect an insurance exchange would be less productive than focused analysis of an actual proposal in its own state environment. There are three federal laws that would affect privately operated purchasing exchanges, however: the antitrust laws, ERISA provisions regulating multiple employer welfare associations (MEWAs), and the HIPAA privacy regulations. These will be briefly considered here.

\section{A. Antitrust Law}

Section one of the Sherman Antitrust Act prohibits "every contract, combination . . . or conspiracy in restraint of trade," while section two prohibits monopolization. ${ }^{81}$ Although the federal antitrust laws are most commonly enforced against sellers of products and services, they also prohibit unreasonable restraints of trade imposed by buyers. Monopsony, or the domination of a market by a buyer, just like monopoly can distort markets, and can potentially reduce the quantity and quality of available products.

The explicit purpose of an insurance exchange is to restrain trade since it organizes the purchase of insurance by individuals and groups. Insurance exchanges can potentially achieve near monopsonistic market power in the private insurance market.

At the same time, antitrust law has long permitted purchasers to engage in joint ventures, including purchasing cooperatives that enhance efficiency and do not create undue purchaser market power. It is a fair question, therefore, whether the federal antitrust laws would limit insurance exchanges.

To begin, federal antitrust laws do not restrict the authority of the states to establish governmentrun insurance exchanges. The Massachusetts Connector, for example, is not subject to an antitrust challenge. Antitrust law has developed the State Action Doctrine to accommodate the interests of federalism and also permit states to engage in regulatory supervision of commerce in their states. The State Action Doctrine exempts state entities from federal antitrust law if their conduct is compelled or clearly authorized by state law. If the state law pertains to conduct by private actors, that conduct must be compelled or authorized and must be actively supervised by the state. ${ }^{82}$ Situations arise, however, in which the state explicitly or impliedly authorizes or encourages actors to engage in conduct that violates federal antitrust law, but the level of state supervision may fall short of that required under Supreme Court precedent. Thus, the State Action Doctrine would not apply, leaving the conduct exposed to antitrust enforcement.

If an insurance exchange is created solely by private action, for example, by a coalition of private employers, there is by definition a combination of actors, leaving only the question of whether this combination is a restraint of trade. This is a complex question, the answer to which depends

O’NEILl INSTITUTE FOR NATIONAL AND GLOBAL HEALTH LAW

GEORGETOWN LAW | 600 NEW JERSEY AVENUE NW | WASHINGTON, DC 20001 www.oneillinstitute.org 
heavily on the factual situation of a particular exchange. The issues raised by antitrust law for insurance exchanges were analyzed thoroughly by Clark Havighurst a decade ago, ${ }^{83}$ and a decade earlier by H. Robert Harper and John J. Miles, ${ }^{84}$ and their analysis will not be repeated in detail here.

A few salient points can, however, be made. First, as already noted, private purchasing coalitions are problematic under the federal antitrust laws. Courts applying the antitrust laws may be somewhat less troubled by buyer than by seller cartels, but restraints of trade imposed by buyers can still be antitrust violations. Second, naked price restraints imposed by a combination of buyers and lacking any efficiency justifications can be per se violations of the antitrust lawsthat is, illegal regardless of any other justification that may be offered. In most instances, however, courts will evaluate purchasing coalitions under the rule of reason - that is, review their legality in the context of their particular market and consider their "pro" and "anti" competitive effects. Applying the rule of reason, courts will be concerned with pro-competitive justifications for joint purchasing arrangements. Given the market failures present in health care, it may be quite possible to justify joint purchasing as efficiency enhancing in many situations. ${ }^{85}$ In particular, purchasing pools are pro-competitive insofar as they offer individuals and small employers the chance to achieve risk pooling and economies of scale not otherwise available. Third, if an exchange does nothing more than organize a market for insurance without negotiating prices, for example, by providing information, structuring choices, and discouraging adverse selection, it is unlikely to be found in violation of the antitrust laws. Indeed, such activities may increase rather than suppress competition. ${ }^{86}$

A coalition without excessive market power is probably safe in any event. Defining the relevant product and geographic markets affected by insurance exchanges itself is a complicated endeavor. Antitrust cases have in various contexts identified insurance markets on the "sell side," the markets in which insurers sell their products, as including individual and small groups, and excluding larger employers and self-insured plans. The 'buy side' market, in which insurers compete with other purchasers in purchasing services, such as physician services, may include other purchasers such as Medicare and Medicaid, and not be limited to private insurers only. A market must be defined for the market share to be determined. If the market is defined narrowly enough, insurance exchanges affecting private plans may be found to have large market shares, but if the market is defined broadly, their share may not be troublesomely large.

The Department of Justice, Federal Trade Commission Statement on Antitrust Enforcement Policy in Health Care on Joint Purchasing Arrangements creates a safe harbor for health care providers whose "purchases account for less than 35 percent of the total sales of the purchased product or services in the relevant market," ${ }^{, 87}$ a market-percentage that would probably apply to insurance purchasing as well. However, a coalition that offers its members access to a wide variety of insurance plans and products is unlikely to be found to be in restraint of trade even if its share is larger.

Currently existing private insurance exchanges have tended to control only a small share of the market, and thus not to pose antitrust problems. If this were to change, Congress could amend the antitrust laws to exempt health insurance exchanges that allow the participation of multiple insurers from antitrust scrutiny.

O’NEILL INSTITUTE FOR NATIONAL AND GLOBAL HEALTH LAW GEORGETOWN LAW | 600 NEW JERSEY AVENUE NW | WASHINGTON, DC 20001 www.oneillinstitute.org 
Alternatively, the Department of Justice and Federal Trade Commission could promulgate a new enforcement guideline delineating more clearly the circumstances under which they would consider a private health insurance exchange to be in compliance with the antitrust laws.

\section{B. Multiple Employer Welfare Arrangement Regulation}

A private insurance exchange that offers health insurance to employees is a multiple employer welfare arrangement (MEWA) under ERISA, and thus subject to regulation under state and federal law. The extent to which a private exchange is subject to state or federal regulation depends, however, on the type of MEWA it would regulate. 29 U.S.C. § 1002(40) defines a MEWA as:

an employee welfare benefit plan, or any other arrangement (other than an employee welfare benefit plan), which is established or maintained for the purpose of offering or providing any benefit described earlier in the statute, including health insurance, to the employees of two or more employers (including one or more self-employed individuals), or to their beneficiaries. ${ }^{88}$

An "employee welfare benefit plan," as noted in the above discussion of ERISA , is "any plan, fund, or program which . . is . . established or maintained by an employer or by an employee organization, or by both, . . . for the purpose of providing for its participants or their beneficiaries, through the purchase of insurance or otherwise, []medical, surgical, or hospital care or benefits. . . ."89 Finally, an employer is "any person acting directly as an employer, or indirectly in the interest of an employer, in relation to an employee benefit plan; and includes a group or association of employers acting for an employer in such capacity" (emphasis added). ${ }^{90}$

Under these definitions, if a group of employers gets together to form an insurance exchange, it would almost certainly be a MEWA, but could be either be 1) a MEWA which is also an employee welfare benefit plan under ERISA established or maintained by an "employer,"(which can be a group or association of employers) or 2) a MEWA which is "any other arrangement ... established or maintained for the purpose of offering or providing" health insurance to employees of two or more employers or to self-employed individuals."91 Under the Department of Labor's interpretation of ERISA, a "group or association" of employers can only be an "employer" if it is determined to be a bona fide group of employers, taking into consideration a number of factors, including how members are solicited, who can participate and who in fact participates, the purpose of the organization, any pre-existing relationships among the members, and most importantly, whether the employee-members of the group exercise control over the program. $^{92}$ An exchange formed by an association of employers who do not qualify as a bona fide group or by a private entity other than a bona fide employer group could be an "other arrangement” MEWA, but would not be an employee welfare benefit plan. ${ }^{93}$

MEWAs that are also ERISA plans are fully regulated by ERISA, including its disclosure, fiduciary obligation, HIPAA, and benefit mandate provisions. Thus an insurance exchange that was considered to be an ERISA plan-MEWA could be sued in federal court by its members for breach of fiduciary obligation or for a denial of claims and could not discriminate in premiums or eligibility based on health status. A MEWA that is not an employee welfare benefit plan is not itself regulated by ERISA, but each participating employer is considered to each have independently established a single-employer plan subject to ERISA. ${ }^{94}$ The administrators of a

O’NEILL INSTITUTE FOR NATIONAL AND GLOBAL HEALTH LAW

GEORGETOWN LAW | 600 NEW JERSEY AVENUE NW | WASHINGTON, DC 20001 www.oneillinstitute.org 
non-ERISA plan MEWA are nonetheless still likely to be held to be fiduciaries insofar as they have discretionary duties in administering the terms of the constituent employers' ERISA plans. ${ }^{95}$ Federal law also requires MEWAs to file with the Department of Labor. ${ }^{96}$

Under the 1983 Erlenborn Amendment, states are empowered to regulate ERISA plans that are also MEWAs. This amendment to ERISA allows states to regulate both insured and self-insured MEWAs that are ERISA plans, effectively exempting them from the preemptive power of ERISA provisions that prohibit the states from regulating self-insured plans. ${ }^{97}$ By definition, insurance exchanges would be insured rather than self-insured MEWAs, since exchanges exist to organize a market in which several insurers offer plans to exchange participants rather than offer insurance themselves. Under this section of ERISA states are limited in their authority to regulate insured MEWAs. ${ }^{98}$ States may only impose, "standards, requiring the maintenance of specified levels of reserves and specified levels of contributions, which any such plan, or any trust established under such a plan, must meet in order to be considered under such law able to pay benefits in full when due" on an insured MEWA. ${ }^{99}$ This would rarely be relevant to insurance exchanges, since they do not normally bear risk. States may also presumably regulate any insurer that sells insurance through an exchange because regulation of insurers would be saved from preemption under the general ERISA savings clause, which saves state insurance regulation from preemption. ${ }^{100}$ But the state regulation would probably have to apply to all insurers in the market, which could be the small group or individual market, not just to insurers participating in a particular exchange.

Finally, states may regulate private insurance exchanges that might be classified as MEWAs, but are not ERISA plans, under the states' inherent police power, since state regulation of MEWAs that are not ERISA plans do not "relate to" ERISA plans. ${ }^{101}$ States may be limited in their ability to provide judicial remedies for beneficiaries against insurers who provide insurance through such MEWAs, however, because beneficiaries are members of their own employer's single-employer ERISA plan, and only secondarily members of the MEWA. Thus actions against the insurers may be considered to be actions against those plans and thus would be preempted by ERISA's remedial provisions. ${ }^{102}$ State law claims brought by employers against a MEWA, on the other hand, are not preempted by ERISA. ${ }^{103}$

Private insurance exchanges are likely to be classified as MEWAs, and thus, in general be subject to state regulation. The power of the states to regulate insurance exchanges operated by "bona fide" employer associations, and thus considered to be ERISA plans, is very limited and does not reach the most important issues that states may want to regulate. Private insurance exchanges that are MEWAs, but not ERISA plans, are subject to state regulation, but are probably also subject to the ERISA requirements that bind plan administrators to the extent that the exchange managers act as administrators of the ERISA plans of the MEWA's member employers. ${ }^{104}$ To date, many states have not yet exercised their authority to regulate MEWAs, and few states have regulated MEWAs effectively. ${ }^{105}$

If Congress adopts comprehensive health insurance reform, but leaves a role for private health insurance exchanges, it could take over responsibility for regulating them or clarify the authority of the states to regulate. If Congress takes no action, states would still be free to exercise their authority to regulate MEWAs that are not operated by "bona fide" employer associations. They may also want to test carefully the status of MEWAs that claim to be ERISA plans since they are largely exempt from state regulation.

O’NEILL INSTITUTE FOR NATIONAL AND GLOBAL HEALTH LAW GEORGETOWN LAW | 600 NEW JERSEY AVENUE NW | WASHINGTON, DC 20001 www.oneillinstitute.org 


\section{HIPAA Data Privacy Requirements}

Private insurance exchanges would, finally, be subject to HIPAA regulations on privacy. ${ }^{106}$ The HIPAA Privacy Rule is discussed at length in another Legal Solutions in Health Reform authored by Deven McGraw so it will only be addressed briefly here. The privacy rule applies to any individually identifiable health information in the hands of covered entities. Covered entities include only health care providers, health plans, and health care clearinghouses. ${ }^{107}$ "Health plans" include most public and private insurers, including those that would participate in insurance exchanges, but would seem not to include an exchange itself. ${ }^{108}$

Health plans may disclose information without consent for 1) treatment, 2) health care operations, which includes "underwriting, premium rating, and other activities relating to the operation, 3) renewal or replacement of a contract of health insurance or health benefits," and 4) payment, which includes "activities undertaken by a health plan to obtain premiums." "109 Health plans may also disclose "de-identified data," 110 which is not covered by HIPAA, and may disclose personal health data, which is covered, to "business associates" with appropriate contractual assurances to safeguard data. ${ }^{111}$ It would seem that health plans could disclose health information regarding their members to health insurance exchanges under one or more of these provisions, subject however, to a further caveat. Health plans, and therefore insurance exchanges as their agents, may only disclose to "plan sponsors" (i.e. employers) de-identified "summary health information" and information as to whether an individual is participating in the sponsor's group health plan. ${ }^{112}$ This would limit information flow from exchanges to employers who purchase insurance through them.

Although HIPAA constraints on the information that health plans can share with exchanges and exchanges with employers are important; data flow in the other direction from employers or employees to exchanges and then to health plans for underwriting or setting premiums is likely to be even more important. Information acquired by a health insurance exchange in this way would in all likelihood only be protected by HIPAA if the exchange were a business associate of a health plan that "allow[ed] a business associate to create or receive protected health information on its behalf." 113 It would be important, therefore, for health insurance exchanges to enter into contracts with health plans that identify the exchange as a "business associate" of the health plans with assurances that the exchange would protect any personal health information it received to be sent on to covered plans. If this is not done, individuals and employers may be reluctant to disclose information to exchanges.

Congress should amend HIPAA to clarify that health insurance exchanges are bound by the HIPAA privacy rule, perhaps by including them within the definition of "health plan" found in HIPAA's language. ${ }^{114}$ Even if Congress fails to amend HIPAA specifically for insurance exchange, private health insurance exchanges could enter into business associate contracts with health care plans whose products they sell and could comply with HIPAA requirements, including limitations on the sharing of identifiable health data with employers.

O’NEILl INSTITUTE FOR NATIONAL AND GLOBAL HEALTH LAW 


\section{Summary of Potential Solutions}

\section{A. Implementation of a Federal Purchasing Exchange}

Congress could constitutionally establish an exchange program operated solely by the federal government, which could be operated either at the national or the regional level. Congress, however, cannot simply command the states to implement a federally established and defined health exchange program. It could, however, use its power to spend money to offer the states financial incentives to encourage them to participate in an insurance exchange program. Alternatively, Congress could invite the states to establish exchanges, but also administer a federally-operated fall-back program for states that decline participation, as it does now with respect to HIPAA provisions. Whatever approach it takes, Congress should make certain that any statute it adopts explicitly notes that the program is being established as one that regulates the business of insurance to forestall challenges under the McCarran-Ferguson Act. If Congress establishes a national purchasing exchange program, it must be aware of other applicable federal administrative law requirements, and either amend relevant laws accordingly or ensure that federal exchanges comply with them.

The Due Process, Equal Protection, and Takings Clauses of the Constitution limit the power of Congress to regulate insurers, although the Constitution prohibits only extreme discriminatory or confiscatory actions, and would not preclude most forms of regulation. Government exchanges that allow all insurers that accept exchange rules to participate in exchanges are unlikely to face successful constitutional litigation. If government exchanges exclude insurers from participating, they should do so according to clearly established guidelines and for clearly articulated purposes.

\section{B. State Exchanges}

If Congress fails to take action to establish a national health insurance exchange, the states could take the initiative to establish exchanges on their own. States initiating purchasing exchanges would be bound by the same constitutional constraints facing the federal government, in addition to the peculiarities of state constitutions, which, in some instances, impose greater restraints on economic regulation.

State exchanges will also need to comply with state administrative law and other laws governing state agencies, such as state civil service or purchasing requirements. States establishing insurance exchanges will need to clarify relationships between the exchange and other state agencies with jurisdiction over insurance issues. Specifically, an exchange could be part of the state's Department of Insurance or could be a separate entity.

As it is currently written, ERISA precludes states from requiring employee benefit plans to purchase insurance through exchanges. States may require individuals to do so, however, and may regulate insurers that sell their products through exchanges. States may also require employers who do not offer health insurance to allow their employees to purchase insurance through exchanges with pre-tax dollars using section 125 arrangements. To avoid ERISA challenges, employers will have to be careful to ensure that they are not perceived as "endorsing" such arrangements and should not offer discounts only to employees who purchase insurance through the exchange.

O’NEILl INSTITUTE FOR NATIONAL AND GLOBAL HEALTH LAW 
If states allow employee groups to participate in an insurance exchange as groups (i.e. if the employer contributes to or administers the arrangement), HIPAA will require that participating insurers provide insurance on a guaranteed offer and renewability basis. HIPAA also prohibits discrimination in eligibility or premiums based on health status, and limits pre-existing conditions clauses for participating employee groups. HIPAA would probably impose the same requirements for all employees of a particular employer if the employees purchase insurance through section 125 arrangements, even without employer contributions. If a state requires community rating, guaranteed issue and renewal, and limits preexisting conditions clauses within the exchange, and thus, effectively applies HIPAA protections to all exchange participants, the state may avoid the issue of whether employees who participate in the plan under a section 125 arrangement are independently protected by HIPAA.

Congress could amend ERISA and HIPAA to clarify their requirements for insurance exchanges. It is possible that the Internal Revenue Service could, even in the absence of Congressional action, clarify whether or not the use of a section 125 arrangement automatically creates a group plan for HIPAA purposes.

States could consider applying uniform regulation of underwriting, premiums, and benefits both inside and outside of insurance exchanges to avoid exposing exchanges to adverse selection or limiting the ability of exchanges to compete with insurers selling outside the exchange. Alternatively, states could only allow the purchase of insurance through the exchange in specific markets such as individual and/or small group.

\section{Private Insurance Exchanges}

If neither Congress nor the states proceed with establishing insurance exchanges, exchanges could still be created by private entities or associations. Congress could create a special antitrust exemption for private insurance exchanges. The Department of Justice and Federal Trade Commission could also clarify the status of exchanges through issuing an enforcement guideline. States may shield private exchanges from antitrust liability if the state explicitly authorizes and actively supervises the exchanges. If the state does not do so, private exchanges should be prepared to limit themselves to $35 \%$ of the market and/or be able to offer procompetitive justifications for the restraints they impose on the market.

Private exchanges should be aware that their membership and organizational rules will determine whether they are regulated primarily by the state or federal government. Under the federal law governing MEWAs, "bona fide" employer association exchanges will be primarily regulated by ERISA, while other exchanges by the states. Congress could, of course, expand the power of the states to comprehensively regulate all MEWAs or could extend federal authority over them.

Since HIPAA could implicate private exchanges and the exchange of protected health information, Congress could amend HIPAA's privacy rules to specifically clarify that they cover health insurance exchanges. If Congress fails to amend HIPAA, exchanges could enter into business associate agreements with insurers to the extent that they will need to access health data on insureds. To avoid legal challenges and to protect privacy, exchanges should not disclose personal health data to employers except to the extent permitted by HIPAA.

O’NEILl INSTITUTE FOR NATIONAL AND GLOBAL HEALTH LAW 


\section{Conclusion}

Health insurance purchasing exchanges have been proposed as a possible means of making insurance more accessible, increasing competition among health plans, and promoting choice of insurer. President Obama and congressional leaders have proposed establishing insurance exchanges through federal legislation. There are no serious constitutional bars to Congress'

establishing an insurance exchange, although the Constitution might limit the means that Congress could use if it chose to implement an insurance exchange program through the states. Alternatively, Congress could amend a number of laws such as ERISA, HIPAA, and the antitrust laws to ease the creation of state or private purchasing exchanges. Even in the absence of any congressional action, however, the creation of purchasing exchanges by the states or by private entities and associations are not likely to be precluded by legal considerations. State and private purchasing exchanges do raise a number of important legal issues, however, that would need to be considered by any state or private entity creating an insurance exchange program. 
${ }^{1}$ Robert L. Willett Family Professor, Washington and Lee University School of Law. The author wishes to thank Patricia Butler, Thomas Greaney, James Blumstein, Amy Monahan, Christie Hager, Gary Bacher, and the O’Neill Institute Management Team who provided valuable feedback on earlier drafts.

${ }^{2}$ The literature on exchanges is vast, but a useful sampling of recent papers would include A. Lischko, "Health Insurance Connectors \& Exchanges: A Primer for State Officials,” Academy Health Stateside, Sept. 2007, available at http://www.statecoverage.net/pdf/healthinsurance0907.pdf (last visited Dec. 12, 2008); E.F. Haislmaier, "State Health Reform: How Pooling Arrangements can Increase Small-Business Coverage,” Heritage Foundation WebMemo 1563, July 23, 2007, available at http://www.heritage.org/Research/HealthCare/wm1563.cfm (last visited Dec. 12, 2008); J. Solomon, "Health Insurance "Connectors" Should be Designed to Supplement Public Coverage, Not Replace It,” Center on Budget and Policy Priorities, Jan. 29, 2007 available at http://www.cbpp.org/1-29-07health.htm (last visited Dec. 12, 2008); M. Kofman, "Group Purchasing Arrangements: Issues for States,” State Coverage Initiatives Issue Brief, 4, No. 3 (Apr. 2003): 1-6. One older article also worth reading is M. A. Hall, "The Role of Insurance Purchasing Cooperatives in Health Care Reform," Kansas Journal of Law \& Public Policy, 3 (1993-94): 95. Empirical studies of health insurance exchanges include, K. Bender and B. Fritchen, "Government-Sponsored Health Insurance Purchasing Exchanges: Do They Reduce Costs or Expand Coverage for Individuals and Small Employees," Oliver Wyman Actuarial Consulting, Inc., 2008, available at http://www.oliverwyman.com/de/pdffiles/health_ins_purchasing_arrangements.pdf (last visited Dec. 12, 2008); "Insurance Markets: What Health Insurance Pools Can and Can’t Do," California Health Care Foundation Issue Brief, 2005, available at http://www.chcf.org/documents/insurance/WhatHealthInsurancePoolsCanAndCantDo.pdf (last visited Dec. 15, 2008); E.K. Wicks, "Health Insurance Purchasing Cooperatives,” Commonwealth Fund Issue Brief, Nov. 2002, available at http://www.commonwealthfund.org/usr_doc/wicks_coops.pdf?section=4039 (last visited Dec. 15, 2008); R. E. Curtis, et al., "Consumer-Choice Purchasing Pools: Past Tense, Future Perfect?," Health Affairs, 20, no. 1 (2001): 164-68; S.H. Long and M.S. Marquis, "Have Small-Group Purchasing Alliances Increased Coverage?,” Health Affairs, 20, no. 1 (2001): 154-63; E.K. Wicks and M. A. Hall, "Purchasing Cooperatives for Small Employers: Performance and Prospects,” Milbank Quarterly, 78 (2000): 511.

${ }^{3}$ Senator McCain's plan did not include insurance exchange proposals.

${ }^{4}$ S. 2795, $110^{\text {th }}$ Cong. 2008.

${ }^{5}$ These arrangements, authorized by section 125 of the Internal Revenue Code, allow employees to pay for various benefits with their own income on a pre-tax basis.

${ }^{6}$ See R. E. Moffit, "State-Based Health Reform: A Comparison of Health Insurance Exchanges and the Federal Employees Health Benefit Program,” Heritage Foundation WebMemo, June 20, 2007, available at http://www.heritage.org/research/healthcare/wm1515.cfm (last visited Dec. 16, 2008).

${ }^{7}$ Barak Obama’s Plan for a Healthy America, no longer available on-line.

${ }^{8}$ Id.

${ }^{9}$ Id.

${ }^{10}$ S. 334, $110^{\text {th }}$ Cong. 2008.

${ }^{11}$ Some commentators attempt to draw a clear distinction between the purchasing cooperatives and health alliances that were widely discussed in the 1970s, 80s and 90s and were at the heart of the Clinton Health Security Act, and the contemporary health insurance exchange. See Lischko, supra note 2 at 2; Moffit, supra note 6 . Because the terms purchasing cooperative, health alliance, and health insurance exchange cover or have covered a broad assortment of models among which there is considerable variety and overlap, I do not believe it is possible to draw a clear line between the modern insurance exchange and its antecedents. (See Bender \& Fritchen, supra note 2 at 12, for an analysis of exchanges written for the Blue Cross/Blue Shield Association that strongly supports this conclusion.) Insofar as there are differences, they are 1) that health insurance exchanges, as some commentators define them, do not act as purchasing agents or regulators but rather simply connect insurance purchasers with insurers, and 2) that some commentators in the past have included as purchasing cooperatives entities that purchase services directly from providers, while contemporary health insurance exchanges generally contract only with insurers. Believing that the terms are in fact largely interchangeable, I will use the term insurance exchange throughout this paper instead of the terms purchasing cooperative (or pool) or health alliance.

${ }^{12}$ These include, by one list, California, Connecticut, Georgia, Kansas, Maryland, Michigan, Minnesota, Missouri, Montana, New Jersey, Oregon, Texas, Virginia, Washington, and Wisconsin. See J. E. Schneider, et al., "Legal and Economic Analysis of Health Insurance Exchange Mechanisms," Health Economics Consulting Group, 2007, available at http://www.hecg-llc.com/health_care_regulation.htm (last visited Dec. 16, 2008).

${ }^{13}$ See C. L. Hager, "Massachusetts Health Reform: A Social Compact and a Bold Experiment," University of Kansas Law Review, 20 (2007): 1313-29. M.A. Chirba-Martin, "Universal Health Care in Massachusetts: Setting the Standard for National Reform,” Fordham Urban Law Journal, 35 (2000): 409-449.

O’NEILl INSTITUTE FOR NATIONAL AND GLOBAL HEALTH LAW GEORGETOWN LAW | 600 NEW JERSEY AVENUE NW | WASHINGTON, DC 20001 www.oneillinstitute.org 
${ }^{14}$ See Hager, supra note 13; E. A. Zelinsky, "The New Massachusetts Health Law: Preemption and Experimentation,” William and Mary Law Review, 49 (2007): 229-87, 235.

${ }^{15}$ Hager, supra note 13 at 1316.

${ }^{16}$ See E.K. Wicks and M.A. Hall, "Purchasing Cooperatives for Small Employers: Performance and Prospects, 78 Milbank Quarterly 511: (2000).

${ }^{17}$ See, e. g. J. Quadagno, One Nation Uninsured: Why the U.S. Has no National Health Insurance (New York: Oxford University Press, 2005).

${ }^{18}$ See H.T. Greely, "Policy Issues in Health Alliances: Of Efficiency, Monopsony, and Equity,” Health Matrix, 5 (1995): 37-81.

${ }^{19}$ United States v. South-Eastern Underwriters Association, 322 U.S. 533 (1944).

${ }^{20} 15$ U.S.C. § 1011 (2007).

${ }^{21}$ Printz v. United States, 521 U.S. 898 (1997); New York v. United States, 505 U.S. 144 (1992); C. Hoke, "Constitutional Impediments to National Health Reform: Tenth Amendment and Spending Clause Hurdles," Hastings Constitutional Law Quarterly, 21 (1994): 489-575.

${ }^{22}$ This is the approach Congress took with the portability provisions of the Health Insurance Portability and Accountability Act, 42 U.S.C. §§ 300gg-22(a)(2) and 300gg-44(b)(3)(2007), and with eliminating state limits on high deductible policies coupled with health savings accounts. See T. S. Jost and M. A. Hall, "The Role of State Regulation in Consumer-Driven Health Care,” American Journal of Law \& Medicine, 31 (2005): 395-418.

${ }^{23}$ See South Dakota v. Dole, 483 U.S. 203, 206 (1987); New York v. United States, 505 U.S. 144 (1992). Another issue that might arise involves the provisions of the Constitution that require uniform taxation among the states. See U.S. Const. Art. 1, Sec. 2, cl. 3; U.S. Const. Art. 1, Sec. 8, cl. 1. If the federal government were to require individuals to purchase insurance through purchasing exchanges, the premiums might be characterized as taxes, and if premiums varied from state to state or region to region, as would be likely, the question of whether these "taxes" were direct and uniform would need to be reached. This is a difficult question, but would probably ultimately not prove an insurmountable barrier to the establishment of exchanges by federal law. It is discussed comprehensively by H. Greely, supra note 18, and will not be addressed further here.

${ }^{24}$ See B. Schwartz, The Paradox of Choice: Why More is Less, (New York: Harper Perennial, 2004).

${ }^{25}$ If exchanges are private entities, on the other hand, their exclusionary or regulatory practices will not raise constitutional issues, as private entities are not bound by the constitutional provisions discussed here.

${ }^{26}$ U.S. Const. Art. 1, Sec. 10, cl. 1. The Due Process and Takings Clauses are found in the $5^{\text {th }}$ Amendment, and the States' Due Process and Equal Protection Clauses are found the $14^{\text {th }}$ Amendment.

${ }^{27}$ See, e.g. Exxon Corp. v. Eagerton, 462 U.S. 176 (1983); Williamson v. Lee Optical Co., 348 U.S. 483 (1955).

Some states, however, have interpreted their state constitutions more restrictively to strike down economic regulation. See, e.g. In re Certificate of Need for Aston Park Hosp. Inc., 193 S.E.2d 729 (N.C.1973).

${ }^{28}$ Energy Reserves Group Inc. v. Kansas Power \& Light Co., 459 U.S. 400, 410 - 412 (1983); Liberty Mut. Ins. Co. v. Texas Dept. of Ins., 187 S.W.3d 808 (Tx. App. 2006).

${ }^{29}$ Connelly v. Pension Benefit Guar. Corp. 475 U.S. 211 (1986); Vesta Fire Ins. Corp. v. State of Fla., 141 F.3d 1427 (11 $1^{\text {th }}$ Cir. 1998).

${ }^{30}$ See O'Gorman \& Young, Inc. v. Hartford Fire Ins. Co., 282 U.S. 251 (1931); Gerling Global Reinsurance Corp. of America v. Low, 296 F.3d 832 (9 ${ }^{\text {th }}$ Cir. 2002); Stephens v. State Farm Mut. Auto. Ins. Co., 894 S.W.2d 624 (Ky 1995) (discussing the application of the takings clause to insurance regulation cases).

${ }^{31}$ Health Ins. Ass'n of America v. Harnett, 44 N.Y.2d 302, 376 N.E.2d 1280, 1284-1285, 405 N.Y.S.2d 634, 639 (1978).

${ }^{32}$ New Hampshire-Vermont Health Service v. Whaland, 119 N.H. 886, 410 A.2d 642 (1979).

${ }^{33}$ Golden Rule Ins. Co. v. Stephens, 912 F.Supp. 261 (E.D.Ky. 1995).

${ }^{34}$ See, e.g. Massachusetts Indem. and Life Ins. Co. v. Texas State Bd. of Ins., 685 S.W.2d 104 (Tex.App.1985) (limiting the number of temporary life insurance agents available to an insurer); Matter of Plan for Orderly Withdrawal From New Jersey of Twin City Fire Ins. Co., 591 A.2d 1005 (N.J. Super .A.D.1991) (prohibiting an insurer from continuing to do business in some insurance lines if it dropped others). Although insurance regulations generally survive due process challenges, they are usually challenged in state court and some states have their own particular lines of doctrinal development. In Florida, for example, statutes that prohibit discounted sales of insurance have been held unconstitutional. Chicago Title Ins. Co. v. Butler, 770 So.2d 1210 (Fla. 2000); Department of Insurance v. Dade County Consumer Advocate's Office, 492 So.2d 1032 (Fla.1986).

${ }^{35}$ Goodin v. State of Oklahoma, ex rel. Oklahoma Welfare Commission, Dept. of Institutions, Social and Rehabilitative Services, 436 F.Supp. 583 (D.C.Okl. 1977); Attoma v. State Department of Social Welfare, 270 N.Y.S.2d 167 (1966); Merry Heart Nursing and Con. Home v. Dougherty, 330 A.2d 370 (1974).

${ }^{36}$ United Seniors Ass'n, Inc. v. Shalala, 2 F.Supp.2d 39 (D.C.1998).

O’NEILl INSTITUTE FOR NATIONAL AND GLOBAL HEALTH LAW GEORGETOWN LAW | 600 NEW JERSEY AVENUE NW | WASHINGTON, DC 20001 www.oneillinstitute.org 
${ }^{37}$ R. E. Brown, “Constitutional Limits on State Insurance Regulation,” Tort \& Insurance Law Journal, 29 (1994): 651-683.

${ }^{38}$ Colonial Life Ins. Co. v. Curiale, 617 N.Y.S.2d 377 (1994).

${ }^{39}$ F.P.C. v. Hope Natural Gas, 320 U.S. 591 (1944) (analyzing the implications of the takings clause for utility ratesetting).

40 5 U.S.C. §§ 552, 552a, 552b, 553, 554 \& 702 (2007).

${ }^{41}$ These can be found at the Open Government Guide, available at http://www.rcfp.org/ogg/index.php (last visited Dec. 16, 2008) and the Freedom of Information Center of the Missouri School of Journalism, available at http://www.nfoic.org/state-foi-laws (last visited Dec. 16, 2008).

${ }^{42}$ Presumably much of the information received by insurance exchanges would be exempt from public disclosure under state law equivalents to the federal freedom of information act exemptions for "commercial and financial information obtained from a person and privileged and confidential,” 5 U.S.C. § 552(b)(4)(2008), and "personnel and medical files and similar files the disclosure of which would constitute a clearly unwarranted invasion of personal privacy.” 5 U.S.C. § 552(b)(6) (2008).

${ }^{43}$ NAIC Model Laws, Regulations and Guidelines 78-1, Table of Contents.

${ }^{44} 29$ U.S.C. § 1144 (2007).

45 Shaw v. Delta Airlines, 463 U.S. 85, 97 (1983).

4629 U.S.C. § 1132. See Aetna Health Inc., v. Davila, 542 U.S. 200, 201 (2004).

${ }^{47}$ The MEWA provisions of ERISA, however, allocate responsibility between the federal and state government to regulate private purchasing pools. See section III below.

4829 U.S.C. § 1144(b)(2)(A) (2007).

${ }^{49}$ One commentator has observed that if a state requires every resident to be covered by a health insurance policy, meeting specific minimum coverage requirements, it effectively requires employers to provide that level of coverage, which could raise ERISA concerns. See Zelinsky, supra note 14 at 276.

${ }^{50} 29$ U.S.C. $\S 1144$ (a) (2007).

${ }^{51}$ Cf. Retail Industry Leaders Ass' v. Fielder, 475 F.3d 180 (4 ${ }^{\text {th }}$ Cir. 2007); Retail Industry Leaders Ass'n v. Suffolk County, 497 F.Supp.2d 403 (E.D.N.Y. 2007) (finding ERISA preemption of Maryland and New York pay or play laws) and Golden Gate Restaurant Ass'n v. City and County of San Francisco, 546 F.3d 639, 2008 WL 4401387 (9 Cir. 2008) (finding no preemption). This issue is discussed in another Legal Solutions in Health Reform Paper authored by Peter Jacobson, JD, MPH. See also A. B. Monahan, "Pay or Play Laws, ERISA Preemption, and Potential Lessons from Massachusetts," University of Kansas Law Review, 55 (2007): 1203-1232; P. A. Butler, ERISA Implications for State Health Care Access Initiatives: Impact of Maryland "Fair Share Act: Court Decision, Academy Health State Coverage Initiatives, 2006, available at http://www.statecoverage.net/SCINASHP.pdf (last visited Dec. 16, 2008).

${ }^{52}$ Mackey v. Lanier Collection Agency, 486 U.S. 825 (1988).

${ }^{53}$ For the analysis in this section and in the section on HIPAA that follows, I am greatly indebted to Amy Monahan, Mark Hall, and Pat Butler. A monograph on "Section 125 Plans for Individual Insurance and HIPAA's Group Insurance Provisions," by Amy Monahan and Mark Hall was made available to me as I was drafting this paper and is now available at http://www.phs.wfubmc.edu/public/pub_insurance/HIPAA_125_Policy_Brief_final.pdf (last visited Dec. 16, 2008). See also P. Butler, “Employer Cafeteria Plans: States’ Legal and Policy Issues,” California Healthcare Foundation, Oct. 2008, available at

http://www.chcf.org/topics/download.cfm?pg=insurance\&fn=EmployerCafeteriaPlans\%2Epdf\&pid=511167\&itemi $\mathrm{d}=133770$ (last visited Dec. 16, 2008).

${ }^{54}$ I.R.C. $\S 125$ (1996).

${ }^{55} 29$ U.S.C. § 1002(1) (2007).

${ }^{56}$ See New England Mut. Life Ins. Co. v. Baig, 166 F.3d 1 (1 ${ }^{\text {st }}$ Cir. 1999); O’Brien v. Mutual of Omaha Ins. Co., 99 F.Supp.2d 744 (E.D. La. 1999). Where employers are more involved in the insurance relationships or individual insurance policies seem to be part of a larger employee plan, however, the arrangements will be held subject to ERISA. Burrill v. Leco Corporation, 1998 WL 340781444 (W.D. Mich. 1998).

${ }^{57} 29$ C.F.R. § 2510.3-1(j) (2007).

${ }^{58}$ See, e.g. Butero v. Royal Maccabees Life Ins. Co. 174 F.3d 1207 (11 ${ }^{\text {th }}$ Cir. 1999); Hrabe v. Paul Revere Life Ins. Co., 951 F.Supp. 997, 1001 (M.D.Ala. 1996). There is also a line of ERISA cases that have held that a scheme under which an employer pays for individual insurance premiums on a payroll deduction basis is a group policy if the employee receives a discount that is otherwise not available for purchasing through the employer. See Tannenbaum v. Unum Life, 2006 U.S.Dist. LEXIS 6623 (E.D. Pa. Mar. 18, 2005); Kuehl v. Provident Life \& Accident, 1999 U.Dist. LEXIS 22946 (Sep. 30, 1999). One case has even held that a disability plan was an ERISA plan because it was funded with pre-tax income, Brown v. Paul Revere Life Ins. Co., 2002 WL 1019021 (E.D. Pa.

O’NEILl INSTITUTE FOR NATIONAL AND GLOBAL HEALTH LAW 
2002), although that court seems to have inappropriately applied COBRA regulations in interpreting ERISA and the case is in any event distinguishable from our situation on several grounds. See Butler, supra note 51. Other courts have held, however, that the fact that employees receive a discount for purchasing through their employer does not in itself make a plan an ERISA plan. See, e.g. Rubin v. Guardian Life, 174 F.Supp. 2d 1111 (D.Or. 2001). If the only discount that is offered employees participating in a state insurance exchange is the benefit of paying for insurance using pre-tax income available under $\S 125$, this alone is unlikely to turn the $\S 125$ arrangement into an ERISA plan.

${ }^{59}$ See Schwartz v. Provident Life and Accident, 280 F.Supp. 2d 937 (D.Ariz. 2003); Murdock v. Unum Provident Co., 265 F.Supp. 2d 539 (W.D. Pa. 2002); Merrick v. Northwestern Mutual Life, F.Supp.2d, 2001 WL 34152095 (N.D.Iowa 2001); Byard v. Qualmed Plans for Health, Inc. 966 F.Supp. 354 (E.D. Pa. 1997); Levett v. American Heritage Life Ins. Co., 971 F.Supp. 1399 (M.D. Ala. 1997).

${ }^{60}$ Although there is no authority addressing this question, it would seem that participation by an employee in a statemandated $\S 125$ arrangement would still be "voluntary" under the terms of the safe harbor because it would not be required by the employer, which is the concern of the regulation.

${ }^{61}$ See Butler supra note 51.

${ }^{62}$ U.S. Dept. of Labor, Advisory Opinion 96-12A, July 17, 1996. In the particular situation at issue in the opinion the $\S 125$ arrangement was used to pay premiums for an ERISA plan, and thus became part of the ERISA plan.

${ }^{63} 26$ U.S.C. §§ 9801 (2007); 29 U.S.C. § 1182 (2007); 42 U.S.C. § 300gg-1 (2007); I.R.C. § 9802.

${ }^{64} \mathrm{Id}$.

${ }^{65} 29$ U.S.C. § 1002(1). See 42 USC § 300gg-1 and 42 USC § 300g-91.

66 29 C.F.R. § 2590.702 (2008).

${ }^{67}$ Section 125 also has its own non-discrimination provisions that apply to discrimination in favor of highlycompensated employees and key employees. These provisions are not discussed here (see Butler, supra note 51 at 3-4 for thorough analysis of these provisions.) If they are violated, however, favored employees may not be able to take advantage of the tax advantages offered by $\S 125$.

${ }^{68}$ I.R.C. $\S 5000(b)(1)$.

${ }^{69}$ Dept. of the Treasury, Proposed Rule, 72 Fed. Reg. 43938 (Aug. 6, 2007) to be codified at 26 C.F.R. § 125-1(m). It would seem to make no sense for the Treasury Department to specify that individual policies could be purchased through a § 125 arrangement if all health insurance purchases made through a § 125 arrangement automatically became part of a group health plan due to the fact that $\S 125$ contributions are considered employer contributions for tax purposes.

${ }^{70}$ I.R.C. $\S 125(\mathrm{~d})$ and (f).

${ }^{71}$ See Butler, supra note 51; Monahan, supra note 51 at 3. The one case that has interpreted the tax code definition (for the purposes of a different law that uses the same definition) held that the fact that individual policies paid for on a payroll deduction basis were issued to employees rather than through a group policy conclusively determined that the policies were individual rather than group policies. Brooks v. Blue Cross \& Blue Shield of Florida, 116 F.3d 1364 (11 ${ }^{\text {th }}$ Cir. 1997) (interpreting the definition for the Medicare as secondary payer statute.) This would not, of course, be persuasive authority for interpreting the definition for HIPAA purposes. The tax definition of group plan is also used for COBRA continuation coverage requirements. Regulations implementing COBRA regulation seem to extend the reach of that definition. 26 C.F.R. § 54.4980B-2 provides that insurance provided through individual policies by an employer could constitute group coverage "even if the employer or employee organization does not contribute to it if coverage under the plan would not be available at the same cost to an individual but for the individual's employment-related connection to the employer or employee organization.” This definition is not directly relevant to HIPAA coverage, but might be used by a court to interpret ERISA.

${ }^{72}$ See S.S. Laudicina et al., "State Legislative Health Care and Insurance Issues, 2007 Survey of Plans," BlueCross BlueShield Association, 2007, available at http://www.cahc.net/documents/Acr17.pdf (last visited Dec. 16, 2008).

${ }^{73}$ On coverage mandates, see F.A. Sloan and C. J. Conover, "Effects of State Reforms on Health Insurance Coverage of Adults,” Inquiry, 39 (1998): 118; A. C. Monheit and J. Rizzo, Mandated Health Insurance Benefits: A Critical Review of the Literature, New Jersey Dept. of Human Services and Rutgers Center for State Health Policy, Jan. 2007, available at http://www.cshp.rutgers.edu/Downloads/7130.pdf (last visited Dec. 16, 2008). On rating reforms, see K.I. Simon, “What Have We Learned From Research on Small Insurance Reforms?” in A. C. Monheit and J. C. Cantor, eds., State Health Insurance Market Reform (New York: Rutledge, 2004) and D. Chollet, "What Have We Learned From Research on Individual Market Reforms?” in A. C. Monheit and J. C. Cantor, eds., State Health Insurance Market Reform (New York: Rutledge, 2004).

${ }^{74}$ See Wicks \& Hall, supra note 2 at 535-37.

${ }^{75}$ K. Swartz, Reinsuring Health: Why More Middle Class People are Uninsured and What Government Can Do (New York: Russell Sage, 2006).

O’NEILl INSTITUTE FOR NATIONAL AND GLOBAL HEALTH LAW GEORGETOWN LAW | 600 NEW JERSEY AVENUE NW | WASHINGTON, DC 20001 www.oneillinstitute.org 
${ }^{76}$ It should be noted that the line between private and public purchasing exchanges might not always be bright. The state may become so entwined with private actors that their actions can become state action for purposes of constitutional constraints. See Brentwood Academy v. Tennessee Secondary School Athletic Ass'n, 531 U.S. 288 (2001) (stating actions of private entities will be viewed as state actions when the two are irreparably entwined). ${ }^{77}$ NAIC Model Laws, Regulations and Guidelines, 82-1.

${ }^{78}$ According to the NAIC, 22 states have adopted the Model Act or related legislation or regulations. See also J. L. Kaminski, "Health Insurance Purchasing Cooperatives," OLR Research Report, 2006 available at http://www.cga.ct.gov/2006/rpt/2006-R-0005.htm (last visited Dec. 16, 2008).

${ }^{79}$ See M. Kofman et al., “Association Health Plans: What’s All the Fuss About?,” Health Affairs, 25 no. 6 (2006): 1591-1602.

${ }^{80}$ M. A. Hall, “The Geography of Health Insurance Regulation,” Health Affairs, 19 no. 2, (2000): 173-184 at 178179.

81 15 U.S.C. $\S \S 1 \& 2$ (2007).

${ }^{82}$ California Retail Liquor Dealers Ass'n v. Midcal Aluminum, Inc., 445 U.S. 97 (1980); Parker v. Brown, 317 U.S. 341 (1943); J. Blumstein, "Health Care Reform and Competing Visions of Medical Care: Antitrust and State Provider Cooperation Legislation,” Cornell Law Review, 79 (1994): 1459-1506; F. Miller, "Health Insurance Purchasing Alliances: Monopsony Threat or Procompetitive Rx for Health Sector Ills?” Cornell Law Review, 79 (1994): 1546-1572.

${ }^{83}$ C. Havighurst, “Antitrust Issues in the Joint Purchasing of Health Care,” Utah Law Review, 1995 (1995): 409450.

${ }^{84}$ H. R. Harper and J.J. Miles, Antitrust Guide for Health Care Coalitions (George Washington University: National Health Policy Forum, 1983).

${ }^{85}$ See T. Greaney, “Quality of Care and Market Failure Defenses in Antitrust Health Care Litigation,” Connecticut Law Review, 21 (1989): 605-665. In a 1994 business review letter, the Department of Justice stated that it would not challenge a purchasing group representing sixteen large private firms and the California Public Employees Retirement System that proposed to negotiate a price for two standard benefit plans with Health Maintenance Organizations (HMOs) for its members, with an understanding that the members would not negotiate independently with the HMOs (although they could contract outside the group with other HMOs), because the Justice Department concluded that the arrangement had the potential to create efficiencies and bring about lower health care costs. Bay Area Business Group on Health, Letter Number 94-4, Trade Regulation Reporter (CCH), ๆ 44,094 (Feb. 18. 1994).

${ }^{86}$ Chicago Board of Trade v. United States, 246 U.S. 231 (1918); Havighurst, supra note 83 at 417.

${ }^{87}$ See U.S. Dept. of Justice, Statements of Antitrust in Health Care Policy Issued By the Dept. of Justice and Federal Trade Commission, Aug. 1996, 68 available at http://www.usdoj.gov/atr/public/guidelines/0000.pdf (last visited Dec. 16, 2008).

${ }^{88} 29$ U.S.C. § 1002(40) (2008).

${ }^{89} 29$ U.S.C. § 1002(1) (2008).

${ }^{90} 29$ U.S.C. § 1002(5) (2008).

${ }^{91}$ It could perhaps be argued that insurance exchanges are not formed for the purpose of "offering or providing" benefits, but rather merely to facilitate access to insurers who independently offer benefits. This seems to be an implausible argument.

${ }^{92}$ U.S. Dept. of Labor, "MEWAs: Multiple Employer Welfare Arrangements under the Employee Retirement Income Security Act (ERISA): A Guide to Federal and State Regulation,” 2004, available at http://www.dol.gov/ebsa/pdf/mwguide.pdf (last visited Dec. 16, 2008); S. Stadtmauer, "Self-Insured MEWAs: Are the Risks Worth the Reward?,” Quinnipiac Health Law Journal, 7 (2003-4): 284-87.

${ }^{93}$ Moideen v. Gillespie, 55 F.3d 1478 ( $9^{\text {th }}$ Cir. 1995).

${ }^{94}$ U.S. Dept. of Labor, supra note 92.

${ }^{95}$ See Donovan v. Dillingham, 688 F.2d 1367 (11 ${ }^{\text {th }}$ Cir. 1982); Chao v. Crouse, 346 F.Supp.2d 975 (S.D.Ind. 2004.). They may also be subject to other ERISA obligations imposed on administrators as opposed to obligations imposed on plans. See, e.g., 29 C.F.R. § 29 C.F.R. § 2560.503-1(f) - (j) (2007).

${ }^{96}$ U.S. Dept. of Labor, Employee Benefits Security Administration, "FAQS on the Form M-1," available at http://www.dol.gov/ebsa/faqs/faq-FormM1.html (last visited Dec. 16, 2008).

9729 U.S.C. § 1144(b)(2)(B) (2008).

${ }^{98} 29$ U.S.C. § 1144(b)(6)(A) (2008).

${ }^{99} \mathrm{Id}$.

${ }^{100}$ Under 29 U.S.C. § 1144, a MEWA is considered to be "fully insured”, "only if the terms of the arrangement provide for benefits ... guaranteed under a contract, or policy of insurance, issued by an insurance company, 
insurance service, or insurance organization, qualified to conduct business in a State.” 29 U.S.C. § 1144(b)(6)(D) (2008).

${ }^{101}$ MDPhysicians \& Associates, Inc. v. State Bd. of Ins, 957 F.2d 178 ( $5^{\text {th }}$ Cir. 1992).

${ }^{102}$ Niethammer v. Prudential Ins. Co. of America, 2007 WL 1629886 (E.D.Mo. 2007); May Hollingshead v. Matsen, 40 Cal.Rptr.2d 603 (Cal.App. 1995).

${ }^{103}$ Independent Distributors Co-op. USA v. Advanced Ins. Brokerage of America, Inc. 264 F.Supp.2d 796 (S.D. Ind. 2003).

${ }^{104}$ Donovan v. Dillingham, 688 F.2d 1367 (11 ${ }^{\text {th }}$ Cir. 1982); Chao v. Crouse, 346 F.Supp.2d 975 (S.D.Ind. 2004).

${ }^{105}$ Stadtmauer, supra note 92 at 268;.M. Kofman et al., "MEWAs: The Threat of Plan Insolvency and Other Challenges," Commonwealth Fund, March 2004 available at

http://www.commonwealthfund.org/usr_doc/kofman_mewas.pdf?section=4039 (last visited Dec. 15, 2008);

M.Kofman et al., "Insurance Markets, Group Purchasing Arrangements: Implications of MEWAs,” California

Healthcare Foundation, Issue Brief, July 2003 available at

http://www.chcf.org/topics/healthinsurance/index.cfm?itemID=21070 (last visited Dec. 15, 2008).

10645 C.F.R. § 164.500 (b) (2007).

10745 C.F.R. §§ 160.103. (2007). Although the term "health care clearinghouses” would seem to apply to insurance exchanges, in fact it refers to specific kinds of entities that standardize health data.

${ }^{108}$ Unless it could be argued that an exchange is described by the part of the health plan definition that refers to "any other individual or group plan, or combination of individual or group plans that provides or pays for the cost of medical care.” 45 C.F.R. §§ 160.103 (2007).

10945 C.F.R. $\S 164.501$ (2007).

11045 C.F.R. $\S \S 164.502(d), 164.514(a) \&$ (b) (2007).

11145 C.F.R. $\S \S 160.103,164.502(\mathrm{e}), 164.504(\mathrm{e})(2007)$.

11245 C.F.R. $\S 160.504$ (a) \& (f) (2007).

${ }^{113} 45$ C.F.R. § 164.502(e)(1)(i) (2007).

11442 U.S.C. $\S 1320 \mathrm{~d}(5)$ (2008). 